Article

\title{
Improving Policy Evidence Base for Agricultural Sustainability and Food Security: A Content Analysis of Life Cycle Assessment Research
}

\author{
Oriana Gava ${ }^{1,2, *}$, Fabio Bartolini ${ }^{1}{ }^{\complement}$, Francesca Venturi $^{1}\left(\mathbb{D}\right.$, Gianluca Brunori ${ }^{1}(\mathbb{D}$ and \\ Alberto Pardossi ${ }^{1}$ (D) \\ 1 Department of Agriculture, Food and Environment, University of Pisa, Pisa 56124, Italy; \\ fabio.bartolini@unipi.it (F.B.); francesca.venturi@unipi.it (F.V.); gianluca.brunori@unipi.it (G.B.); \\ alberto.pardossi@unipi.it (A.P.) \\ 2 Center for Policies and Bioeconomy, Council for Agricultural Research and Agricultural Economics Analysis, \\ Rome 00198, Italy \\ * Correspondence: oriana.gava@agr.unipi.it or oriana.gava@crea.gov.it; Tel.: +39-050-2218984
}

Received: 12 November 2019; Accepted: 27 January 2020; Published: 1 February 2020

check for updates

\begin{abstract}
Life cycle assessment is a widespread method for measuring and monitoring the environmental impacts of production processes, thereby allowing the comparison of business-as-usual with more ecological scenarios. Life cycle assessment research can support evidence-based policy making by comparing and communicating the environmental impacts of agricultural and food systems, informing about the impact of mitigating interventions and monitoring sectoral progress towards sustainable development goals. This article aims at improving the contribution of science to evidence-based policies for agricultural sustainability and food security, while facilitating further research, by delivering a content-analysis based literature review of life cycle assessment research in agricultural and food economics. Results highlight that demand-side and system-level approaches need further development, as policies need to support redesigned agricultural systems and newly conceived dietary guidelines, which combine environmental protection and health benefits, without reducing productivity. Similarly, more research effort towards consequential life cycle assessment and multidimensional assessment may benefit policy makers by considering the rebound effects associated with the large-scale implementation of impact-mitigating interventions. Promising interventions involve the promotion of waste circularization strategies, which could also improve the profitability of agriculture. For effective policy making towards agricultural sustainability and food security worldwide, countries with the greatest expected population growth and raise of urbanization rates need more attention by researchers.
\end{abstract}

Keywords: LCA; sustainability assessment; Social Network Analysis; interventions; pollution; health; rebound effect

\section{Introduction}

Agriculture is facing unprecedented challenges to find a balance between productivity increase and environmental protection [1], and to deal with the quick growth and the raising urbanization rates of the worlds' population [2,3]. The consumption of food and non-edible agricultural products greatly contributes to climate change and environmental risk, with the agricultural phase accounting for the greatest share of the environmental burden [4,5]. By 2050, pollution and resource use from agriculture is projected to worsen in most regions of the world if nothing changes [6]. The reduction in the environmental pressure of agriculture lies at the heart of the United Nations 2030 Agenda for Sustainable Development, being a requirement for ensuring agricultural sustainability and food 
security (Sustainable Development Goal 2, SDG 2), and thereby contributing to the mitigation of climate change and its impacts (SDG 13), and to the prevention of land degradation and biodiversity loss (SDG 15) [7]. Policy makers need scientific evidence for designing and implementing strategies to allow agriculture to contribute to the pursuit of SDGs, by endorsing the sustainable increase in agricultural productivity and promoting actions aimed at climate change mitigation and adaptation, preventing environmental risk and facing resource scarcities [1,7]. At the same time, the viability and competitiveness of the agricultural sector and an adequate income to farmers should be ensured [8].

In the last decade, life cycle assessment (LCA; ISO 14040:2006; ISO 14044:2006) (ISO, Geneva, Switzerland) has gained increasing attention in the academic literature and policy $[9,10]$ for comparing and communicating the environmental impacts and for supporting impact mitigating interventions in agricultural and food systems [4,11], as well as for monitoring sectoral progress towards SDGs [12]. The outputs of research studies that apply the LCA tool target stakeholders, ranging from policy makers to consumers [13], by characterizing production processes in terms of resource use, polluting emissions, and threats to human and ecosystem health, and identifying the necessary interventions to mitigate the environmental impacts [14]. In pursuit of agricultural sustainability and food security goals, policy makers and agribusiness stakeholders should agree on the analytical tool and metrics to support decision-making [15]. Advancing research studies that apply the LCA tool and integrated economic-social-environmental research can help with consensus creation $[14,16]$.

Despite the wide scope for LCA application and development and the growing interest by governments and the research community [10,17], an overview of LCA research in the field of agricultural and food economics is missing. This article aims at providing such an overview to facilitate further research, while avoiding overlapping and reducing uncertainty, thereby improving the contribution of science to evidence-based policies for agricultural sustainability and food security. LCA has tuned into an important decision support tool for agricultural policy makers for identifying, selecting, and guiding interventions to reduce the environmental burden of agriculture and food systems, as well as for setting the objectives and monitoring the impacts of policies. LCA can be applied to monitor the achievements of the agricultural sector with respect to SDGs.

This article proposes a content-analysis-based literature review [18] of LCA research by agricultural and food economists, structured towards the following six themes, identified by authors in related study [19]: (i) approaches to intervention conceptualization, including stakeholders involved in strategy formulation and implementation; (ii) usefulness of information originating from research studies that apply the LCA tool in policy making, (iii) types of LCA; (iv) delivery of multidimensional assessments; (v) recommendations about rebound effect modelling. Theme combinations are also analyzed. The purposes of the study are framing the state-of-the-art and highlighting the needed research developments to form a better evidence base for agricultural and food policy. Many literature reviews exist about environmental LCA and its economic and social variants, focusing on food/diet comparison or methodological issues. Instead, this article focuses on the use of the tool for improving agricultural economics research and its relevance and practical usefulness for decision makers, aiming at achieving SDGs. The methodological approach is innovative by proposing a content analysis of a reproducible literature review and supporting result discussion by applying network analysis to structural and analytic categories, which were deductively derived from the existing literature and inductively created from the retrieved literature, respectively.

\section{Analytical Framework}

Since the 1990s, researchers and policy in advanced economies have raised concerns about the environmental burden of agricultural and food systems. This has resulted in the release of protocols, guidelines, and commitments by governments and international organizations, aiming at burden mitigation. The scientific literature has used the life cycle assessment tool to propose interventions aimed at the mitigation of the environmental impacts of food systems and to generate evidence for policy use. 
In agricultural and food policy, LCA-based information is used for dealing with four issues, viz. pollution leakage, the ex-post transaction costs of environmental regulation, the adoption of the environmentally least harmful (technological) options, and information asymmetry business-to-consumer [10]. LCA studies benefit policy makers by delivering new knowledge about the impacts of existing or innovative products, practices or technologies (information provision), or by guiding the choice among multiple impact mitigating options (passive regulation), or even by highlighting specific parameters that form the basis of a policy measure (e.g., an incentive, tax or subsidy) or an environmental performance standard [10].

Information from stand-alone or comparative LCAs is key for identifying interventions to reduce the environmental impact of agricultural and food systems $[19,20]$. There are three approaches to the conceptualization of impact-mitigating interventions [21]: (i) supply-side, for improving the environmental performance of agriculture; (ii) demand-side, for reducing the consumption of the most impacting foods; (iii) system-level, combining supply and demand-side approaches to propose sustainable synergetic solutions based on redesigned agricultural and food system models [22,23]. Impact mitigating interventions include, e.g., the environmentally sustainable increase of agricultural productivity, the promotion of dietary change to reduce the consumption of animal-based products, and the adoption of efficient waste management practices [24,25]. The reduction in food waste is an additional demand-side intervention [24], which should complement dietary change. Interventions towards food waste reduction are complex, being associated to different steps of the supply chain, different stakeholders and different geographical scales [26]. Those interventions are the subject of a growing body of literature but are beyond the scope of this article. Intervention formulation and implementation require actions by different stakeholders, i.e., governments (design and enforcement), researchers and practitioners (conceptualization, impact assessment, monitoring), private businesses (practice/technology adoption), and the public (behavioral change) (cf. stakeholder theory [27]). A challenge for LCA practitioners is modelling rebound effects (REs), i.e., the behavioral or systemic responses to the introduction of impact mitigating interventions, in lieu of the business-as-usual, following a series of changes in production factors and outputs which affect both producers and consumers $[13,28]$. Behavioral responses involve the production or consumption of a product (direct REs) or its substitutes (indirect REs); systemic responses involve general equilibrium adjustments (economy-wide REs) or society responses to changes in consumers' preferences, social institutions or production organization (transformational REs) [28]. REs may be identified by involving supply chain stakeholders, consumers, authorities, and waste-handlers in participatory analyses [29].

Based on data availability and the objective of the study, researchers can decide to carry out attributional (ALCA), consequential (CLCA) or environmental input-output LCAs (EIO-LCA). To broaden the assessment, many authors have combined LCAs with other decision-making tools [30]. While the combination with economic assessments is widespread [31], coupling LCA with social assessments is less common. The life cycle sustainability assessment has raised the interest of policy makers, because it broadens and deepens the scope of the assessment, by integrating the environmental with both the economic (life cycle costing) and social (social LCA) dimensions, thereby improving the usefulness of the information delivered to decision makers [32-34].

\section{Materials and Methods}

Content analysis is a widespread and flexible technique used in qualitative research, for condensing wide-ranging evidence about a phenomenon $[35,36]$. The technique is applied to texts with different formats (written, audio-video-e.g., interviews-published literature, hypertext, multimedia [37]) to understand the phenomenon under study, presenting facts and creating new knowledge about it, and for guiding action [38-40]. Content analysis relies on texts' classification into categories that represent similar meanings [39]. Researchers create the categories using deductive and/or inductive processes, based on the purpose of the study [36,41]. The deductive approach uses the existing theory to create a system of categories that reflect the subject of study, i.e., moving from the general to the specific; 
instead, the inductive approach moves from the specific to the general, so that observed themes or patterns are combined into general categories [36,41].

The workflow of a content-analysis-based literature review includes material collection, category selection and material evaluation, in that order [18]. The material collection phase should base on a research literature review, with articles as the units of analysis; researchers should present the basic attributes of the units of analysis, such as journal source and publication year [18]. The category selection phase is structured towards the description of the categories that form the basis of content analysis [18]. In the material evaluation phase, researchers apply coding cycles (based on the identified categories) to the selected material; researchers should also evaluate research quality, and present and discuss their findings using analytical tools [18].

Here, the content analysis generates evidence by analyzing the highlighted impact mitigating interventions, under the framework of five research themes (Figure 1).

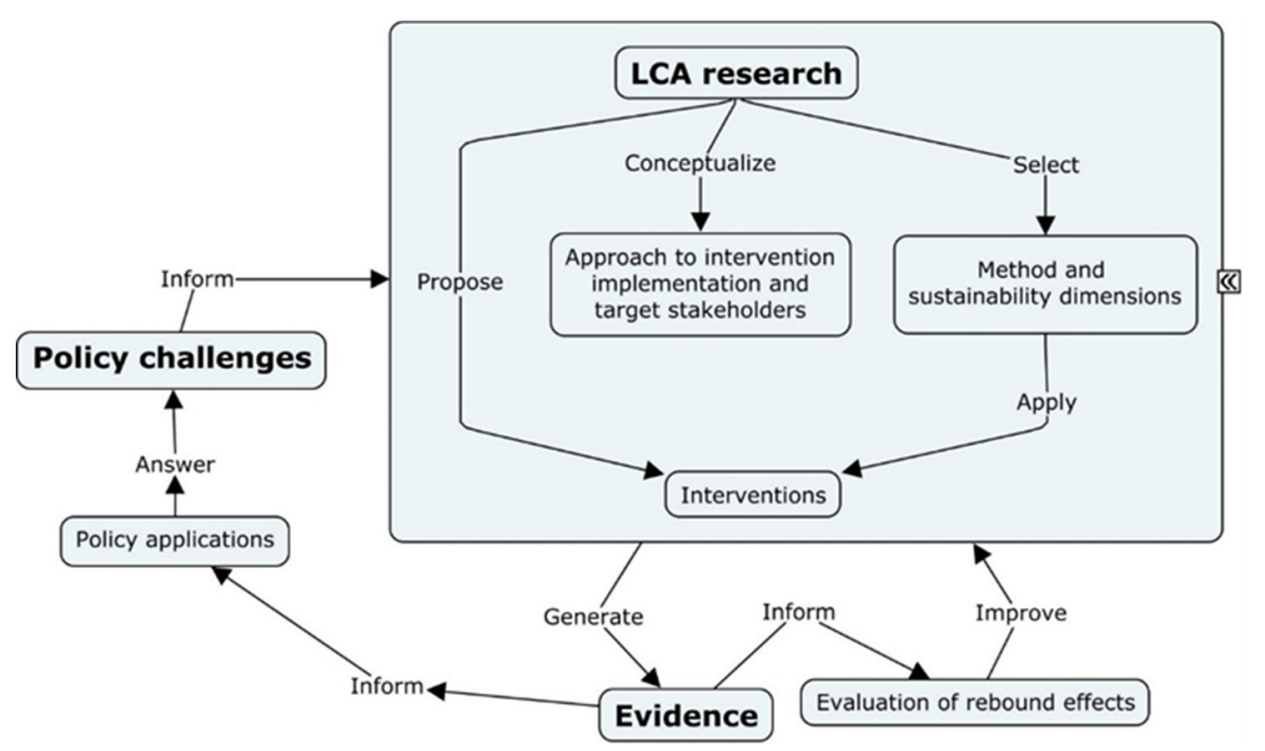

Figure 1. Conceptual framework of the study. LCA: life cycle assessment. Source: authors' own elaboration.

Conceptually, the study creates the connections among the themes to try and stimulate the generation of positive feedback loops among the inputs and outputs of LCA research and the evidence base to improve study findings and enter the policy cycle to answer policy challenges.

The present research, the process of article retrieval is structured towards three iterative steps, viz. selection of bibliographic sources, keyword selection and database search, and application of inclusion/exclusion criteria [42,43]. The applied procedure is common in the scientific literature and allows for study replication and evaluation, thereby reducing researcher bias [44]. To ensure reliability, pairs of authors carried out and cross-reviewed process phases, including coding (cf. [45]. Here, the content analysis is based on a content structuring design, where the creation of a system of both deductive (structural) and inductive (analytic) categories constitutes the central instrument of analysis [41]. The research design was adjusted iteratively and compared with published refereed literature, e.g., [45-47]. The following subparagraphs summarize the stepwise implementation of the research design.

\subsection{Material Collection}

This phase is structured towards four sub-steps, i.e., selection of bibliographic sources, keyword selection and database search, application of inclusion/exclusion criteria, and description of the retrieved material. 
A literature review was carried out in January 2019 (cf. [42,43]) over the Web of Science ${ }^{\mathrm{TM}}$ (WOS) and Scopus $囚$ databases. WOS was selected because of its category structure. Contrary to other major and wider bibliographic databases, notably Scopus, WOS maps Frascati manual's [48] categories and subcategories and includes the "Agricultural Economics and Policy" category (WOS-AEP) [49]. To keep the focus on the article's aim, the WOS search was limited to the "agricultural economics and policy" category (WOS-AEP). Researchers in the fields of agricultural economics and agricultural and food policy may be interested in publishing in WOS-AEP journals for various reasons, such as to increase the visibility of their research among stakeholders involved in the policy cycle and to facilitate the evaluation of their work [50]. The preferred academic journals by agricultural economists are quite a few; scholars' preferences depend on a variety of factors. See [51] and [52] for acknowledgement of scholars' preferences and survey-based lists of relevant journals (23 and 160 journals, respectively) for agricultural economists working in overseas and European contexts. Regardless of the bibliographic database, those journals do not belong to a single category, but are grouped under research areas affiliated to agricultural economics. This complicates comprehensive bibliographic searches, especially because the variety of research areas may hinder the quick selection of policy-oriented papers. Non-researchers may not know all relevant publications and may not be willing to devote too much time to the search [53], thereby turning to WOS-AEP, which covers just a small share of those journals and few additional journals. The reduced number of journals may prevent effective bibliographic searches, especially for relatively new topics in the agricultural economics literature, such as LCA studies. To try and overcome that limit, a Scopus search was carried out to cover preferred journals by agricultural economists. Early search strategies were wide enough in scope to cover major LCA-focused journals, e.g., The International Journal of Life Cycle Assessment or the Journal of Cleaner Production [54,55]. The searches were returning too many papers for effective handling by the research team (ca. 1800). The scope of the review was then narrowed down by excluding the mentioned journals to keep the focus on issues associated with decision making in agricultural policy and mitigate researcher bias throughout papers' selection process, especially concerning excess subjectivity in the application of inclusion/exclusion criteria. Scopus search was limited to preferred journals by agricultural economists, i.e., the journals included in both lists set up by $[51,52]$ (Table A1).

The search was carried out over documents' titles, abstracts and keywords, and was limited to original research and literature reviews written in English and published in academic journals (other document types, e.g., conference papers or book chapters, were explicitly excluded). No cut off criteria were applied to publication years. In WOS-AEP, the search was based on the keyword "life cycle assessment" and returned 17 records. The cited-by and reference lists of those records were screened to highlight additional WOS-AEP publications. Six articles were added. In Scopus, the following string was run "“life cycle assessment" AND (agriculture OR food)". Besides seven duplicates (articles returned from WOS-AEP search), this search returned 57 records. Inclusion/exclusion criteria were applied to abstracts, or to the "methods" section of the article, of the 80 documents identified in the previous step. Articles were included if focusing on agricultural or food production systems (non-food systems, e.g., biogas, should be based on cropped biomass or agricultural waste/by-products), if presenting original research, or if presenting literature reviews/theoretical analyses about LCA. Records reporting about life cycle inventory studies and ISO-compliant carbon and water footprints (respectively, ISO 14064 and ISO 14046) (ISO, Geneva, Switzerland) were included. Articles were excluded if delivering meta-analyses of product impacts or dealing with impact or indicator classification, if developing LCA/footprint calculators, if dealing with outdated issues, or if just addressing activities that occur beyond the farm gate (e.g., olive cake processing or options for food waste reduction). As it was extensively used to build up the analytical framework of this article, [10] was excluded. The full texts of 47 documents were retrieved for review (Table 1 ). 
Table 1. Retrieved articles in chronological order. Articles with the same superscript share at least a co-author. Source: authors' own elaboration.

\begin{tabular}{|c|c|c|c|}
\hline Reference & Year & Journal & Notes \\
\hline$[56]^{\mathrm{a}}$ & 1998 & Food Policy & \\
\hline [57] & 2006 & Ecological Economics & \\
\hline [58] & 2008 & Journal of Environmental Management & \\
\hline [59] & 2009 & Ecological Economics & \\
\hline [60] & 2009 & Journal of Environmental Management & \\
\hline [61] & 2009 & Ecological Economics & \\
\hline$[62]^{\mathrm{b}}$ & 2010 & Journal of Environmental Management & \\
\hline [63] & 2010 & International Food and Agribusiness Management Review & \\
\hline$[64]^{\mathrm{c}, \mathrm{d}}$ & 2010 & Journal of Environmental Management & \\
\hline$[65]^{\mathrm{a}}$ & 2011 & Food Policy & \\
\hline$[66]^{\mathrm{h}}$ & 2011 & Food Policy & \\
\hline$[67]^{\mathrm{b}}$ & 2012 & Journal of Environmental Management & \\
\hline$[68]^{\mathrm{c}}$ & 2012 & Journal of Environmental Management & \\
\hline [69] & 2012 & Agrekon & \\
\hline [70] & 2012 & Food Policy & $\begin{array}{c}\text { Literature } \\
\text { review }\end{array}$ \\
\hline [71] & 2012 & Journal of Environmental Management & \\
\hline$[72]^{\mathrm{e}, \mathrm{f}}$ & 2012 & Journal of Environmental Management & \\
\hline [73] & 2013 & Food Policy & \\
\hline [74] & 2013 & Ecological Economics & \\
\hline$[75]^{\mathrm{g}}$ & 2013 & Agricultural and Resource Economics Review & \\
\hline$[76]^{\mathrm{d}}$ & 2013 & Journal of Environmental Management & \\
\hline [77] & 2013 & Journal of Environmental Management & \\
\hline$[78]$ & 2013 & Journal of Environmental Management & \\
\hline$[79]^{e, f}$ & 2013 & Food Policy & \\
\hline [80] & 2013 & Journal of Environmental Management & \\
\hline$[81]^{\mathrm{e}}$ & 2014 & Food Policy & $\begin{array}{c}\text { Theoretical } \\
\text { analysis }\end{array}$ \\
\hline [82] & 2014 & German Journal of Agricultural Economics & \\
\hline [83] & 2014 & Journal of Environmental Management & \\
\hline [84] & 2014 & Food Policy & \\
\hline [85] & 2015 & EuroChoices & \\
\hline [86] & 2015 & Journal of Environmental Management & $\begin{array}{c}\text { Literature } \\
\text { review }\end{array}$ \\
\hline [87] & 2015 & Journal of Environmental Management & \\
\hline$[88]$ & 2016 & Food Policy & \\
\hline [89] & 2016 & Journal of Environmental Management & \\
\hline [90] & 2016 & Journal of Environmental Management & \\
\hline [91] & 2016 & Food Policy & \\
\hline [92] & 2016 & Journal of Environmental Management & \\
\hline [93] & 2016 & Journal of Environmental Management & \\
\hline$[94]^{\mathrm{h}}$ & 2016 & Food Policy & \\
\hline [95] & 2016 & Journal of Environmental Management & \\
\hline [96] & 2016 & Journal of Environmental Management & \\
\hline [97] & 2017 & European Review of Agricultural Economics & \\
\hline [98] & 2017 & Journal of Environmental Management & \\
\hline [99] & 2017 & Journal of Environmental Management & \\
\hline$[100]$ & 2017 & Journal of Environmental Management & \\
\hline$[101]^{\mathrm{g}}$ & 2017 & Journal of Agricultural and Resource Economics & \\
\hline [102] & 2017 & Journal of Environmental Management & \\
\hline
\end{tabular}


The literature under study is recent, with two thirds of the studies being published in the last five years, and appears in a reduced number of journals, compared to those explored via database search. The Journal of Environmental Management is the most popular journal, followed by Food Policy and Ecological Economics. A quarter of the retrieved articles have at least a shared co-author (Table 1); this may generate a bias by overestimating the importance of some analytic categories. Additional information about the retrieved articles is available from Appendix A.1.

\subsection{Category selection}

A manual coding framework was developed in Excel in an iterative way, by combining the deductive with the inductive approaches to category building [18], based on an iterative workflow [103]. First and second cycle methods were applied, to synthesize, organize and attribute meaning to the literature corpus. The developed coding framework was applied to each unit of analysis to ensure the internal and external validity of the content analysis [45] and was subject to iterative revision by the research team throughout the analytic process.

First cycle coding was carried out in the initial phases of the analytic process, based on a preliminary literature screening and on the existing theory (deductive approach), and included attribute and structural coding. The former had a descriptive purpose. The latter aimed at creating a content-based framework for classifying the literature under review under structural categories, drawing on a the previously defined analytical framework, thereby ensuring construct validity and replicability [45]. Structural categories (Table 2) cover five themes as follows: (i) conceptualization of the approach to impact mitigating interventions and stakeholders [27] called to implement a given impact mitigating practice; (ii) intended practical application of LCA results in policy making; (iii) methodological framework of LCA studies; (iv) addressed dimensions of sustainability; (v) recommendations about the inclusion of rebound effects in further research.

Table 2. Structural categories. Source: authors' own elaboration.

\begin{tabular}{|c|c|}
\hline Category & Description \\
\hline Conceptualization of interventions [21] & Approach to impact mitigation \\
\hline Supply & The agribusiness adopts impact mitigating measures \\
\hline Demand & Consumers reduce the consumption of most impacting items \\
\hline System & Combination of the two above \\
\hline Stakeholders & Executors of interventions to promote impact mitigation \\
\hline Private businesses & Farmers, processors, distributors \\
\hline Public & Consumers: eaters/buyers of food items \\
\hline Researchers and practitioners & Application and development of LCA \\
\hline Government & Measures for natural resource management and public procurement \\
\hline Usefulness in policy making [10] & Policy challenges, and relative applications, of LCA results \\
\hline Least polluting options & Adoption of technology or management to reduce environmental impact \\
\hline Information asymmetry & $\begin{array}{c}\text { Communication of information about the environmental impact of processes/products and suggested } \\
\text { behaviors to reduce impact }\end{array}$ \\
\hline Applications & Usefulness of LCA results in policy making \\
\hline Information provision & $\begin{array}{l}\text { (i) Process hot spots, product impacts, effect of farm characteristics on environmental impact. (ii) Adoption } \\
\text { of innovative technology or transformation of production systems. (iii) LCA modelling }\end{array}$ \\
\hline Passive regulation & $\begin{array}{l}\text { Comparative assertions about well-known technology or management that allow impact mitigation } \\
\text { (process comparisons, scenario analyses) }\end{array}$ \\
\hline Active regulation & Parameters and criteria for promoting given technologies, management, behaviors (e.g., evaluation of rules) \\
\hline Methods & Methodological framework and dimensions of sustainability \\
\hline LCA type & $\begin{array}{l}\text { ALCA (incl. carbon footprint, literature reviews), LCA w/ system expansion, CLCA (incl. literature } \\
\text { reviews, theoretical analysis, EIO-LCA, LCI }\end{array}$ \\
\hline Multidimensional assessments & LCA combination w/ economic or social assessments \\
\hline Evaluation of multiple dimensions & $\begin{array}{l}\text { Environmental, economic, social dimensions and their combinations, addressed by method combinations } \\
\text { or theoretical explanations (e.g., social issues associated w/dietary patterns) }\end{array}$ \\
\hline Rebound effects [28] & Recommendations for inclusion in further research \\
\hline Direct & Changes in production and consumption of the same product as the object of the study \\
\hline Indirect & Changes in production and consumption of a substitute of the object of the study \\
\hline Economy-wide & Modifications that involve the entire economy \\
\hline Transformational & Societal responses \\
\hline
\end{tabular}


Second cycle coding, namely pattern coding, was applied inductively based on material analysis, to highlight repetitive patterns among the studied interventions to improve the environmental performance of agriculture. The identified patterns are the analytic categories of the content analysis (Table 3).

Table 3. Analytic categories: interventions to reduce the environmental externalities of agriculture. Source: authors' own elaboration.

\begin{tabular}{|c|c|}
\hline Category & Description \\
\hline Interventions & Levels of action \\
\hline Farming method & $\begin{array}{l}\text { Cropping and animal husbandry systems (extensive, intensive, } \\
\text { organic, conventional, integrated, flooded, upland, monocropping, } \\
\text { rotations) }\end{array}$ \\
\hline Genetic resources & $\begin{array}{l}\text { Species (plant, animal, animal species), cultivar (hybrid, } \\
\text { conventional), breed (dual or single purpose) }\end{array}$ \\
\hline Health and ethics & $\begin{array}{l}\text { Human health, nutrition security, ecosystem services, animal welfare, } \\
\text { values embedded in impact assessment method }\end{array}$ \\
\hline Processing method & Refining, conservation and cooking methods of foods \\
\hline Production management & $\begin{array}{l}\text { Hot spots based on specific conditions (harvest year, structure, } \\
\text { income, size), including management of farm equipment and } \\
\text { facilities (renovation rate) }\end{array}$ \\
\hline Supply chain management & $\begin{array}{l}\text { Production location (farmland, plants, distribution centers) (and } \\
\text { storage) to reduce the impacts of transportation (and storage), based } \\
\text { on transport routes (distance, road, rail, waterways, means of } \\
\text { transport and fuel type) }\end{array}$ \\
\hline Sustainable intensification & $\begin{array}{l}\text { Management of consumable inputs (fertilizer, livestock feed), field } \\
\text { operations (type of tillage, level of mechanization), livestock density, } \\
\text { rules for land use planning (allocate land to food or feed production } \\
\text { based on land productivity, shrink cropland to allow urbanization) }\end{array}$ \\
\hline Waste circularization & $\begin{array}{l}\text { Apply circular economy concepts to waste management: } \\
\text { waste-to-energy, waste-to-fertilizer, waste-to-new raw material }\end{array}$ \\
\hline Water supply & Irrigation system design \\
\hline
\end{tabular}

\subsection{Material Evaluation}

Based on articles' membership to each category, category frequencies were calculated with respect to the total number of observations. The latter were clustered based on the analytic categories and matrix relationships created among structural and analytic categories. Network analysis [104] was used in the interpretive phases of the study to compel evidence by going beyond the summary of findings and improve the communication of research results $[105,106]$. The tool was selected for its ability to describe and evaluate inter-category relationships. Network analysis drew on article classification under intervention clusters, based on analytic categories. The purpose was the evaluation of intervention clusters based on their ability to support evidence-based policy making to promote impact-mitigating interventions. Then, the network analysis focused on the conceptualization of LCA studies and on their practical usefulness in policy making, by identifying them to key relations, as follows: (i) the "stakeholder involvement for sustainability" relation identifies the sustainability dimensions addressed by the proposed intervention(s) and the stakeholder(s) in charge of adopting the intervention(s); (ii) the "method selection for policy application" relation connects researchers' methodological choices with the practical usefulness of study results for policy applications. The retrieved literature is the unit of analysis: categories are network nodes; category co-occurrences within intervention clusters are category-category links (ties). Two square and valued relational matrices were built: entries are categories; values represent the normalized frequency ( 0 to 1$)$ of category co-occurrence 
within each intervention cluster. The performance of the literature was evaluated graphically in terms of its ability to support evidence-based policy making, via tie strength (approximated by category frequency) and nodes' eigenvector centrality, i.e., a measure of the reciprocal influence among nodes, in terms of their ability to boost information flow [107]. At the node-level, eigenvector centrality (0 to 1) approximates node ability to facilitate information flow across the network. The eigenvector centrality of a node equals 0 when the node is isolated, i.e., it does not show any connection. Tie width ( 0 to 1 ) represents the frequency of category-category connections. When the width equals 0 , the node is isolated. A tie is of maximum width when all articles display the connection it represents. The closer the eigenvector centralities, the more balanced the information flow among network items [107]. The maximum possible number of flows in the network occurs when all nodes are mutually connected, i.e., when they all have the maximum eigenvector centrality (i.e., 1). The identification of network cores (high-centrality nodes connected by high-strength ties) highlight preferred and overlooked categories, and category relationships by researchers, and suggest the area for further development.

\section{Results and Discussion}

This paragraph summarizes research findings. Tables A3 and A4 show article membership to structural and analytic categories and intervention clusters, respectively.

\subsection{Interventions}

Three out of nine interventions cover 50\% of articles (Figure 2).

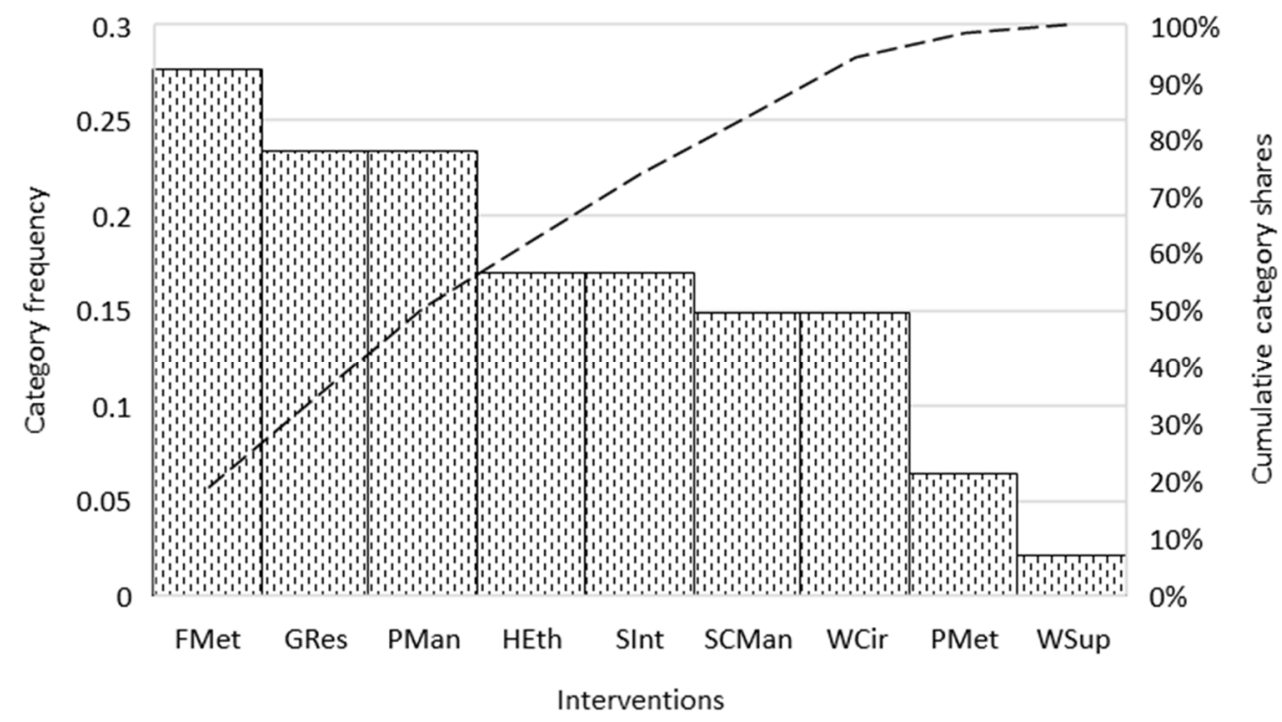

Figure 2. Proposed and assessed interventions. FMet: farming method; GRes: genetic resources; HEth: health and ethics; PMet: processing method; PMan: production management; SCMan: supply chain management; SInt: sustainable intensification; WCir: waste circularization; WSup: water supply. Source: authors' own elaboration.

Most articles propose sets of interventions, with health and ethics, processing method and supply chain management, never studied as stand-alone interventions. Combinations often involve farming methods, genetic resources, and health ad ethics (Table 4). 
Table 4. Combination of interventions. Mutual relationships within the same category indicate stand-alone interventions. FMet: farming method; GRes: genetic resources; Heth: health and ethics; PMet: processing method; PMan: production management; SCMan: supply chain management; Sint: sustainable intensification; WCir: waste circularization; WSup: water supply. Source: authors' own elaboration.

\begin{tabular}{|c|c|c|c|c|c|c|c|c|c|}
\hline & FMet & GRes & PMan & HEth & SInt & SCMan & WCir & PMet & WSup \\
\hline FMet & 6 & 2 & 1 & 1 & 0 & 3 & 0 & 2 & 0 \\
\hline GRes & & 2 & 0 & 5 & 2 & 2 & 0 & 2 & 0 \\
\hline PMan & & & 9 & 1 & 0 & 0 & 0 & 1 & 0 \\
\hline HEth & & & & 0 & 1 & 0 & 0 & 0 & 0 \\
\hline SInt & & & & & 4 & 1 & 0 & 0 & 0 \\
\hline SCMan & & & & & & 0 & 0 & 1 & 0 \\
\hline WCir & & & & & & & 7 & 0 & 0 \\
\hline PMet & & & & & & & & 0 & 0 \\
\hline WSup & & & & & & & & & 1 \\
\hline
\end{tabular}

Production management articles do not propose to improve the environmental performance of farms via the comparison of business-as-usual with the management of technological change. Those articles highlight the issues in existing production systems (hot spots) and relate them to the harvest year, to structural characteristics and value-added creation of farms, to the selection of materials and consumable inputs, to the management of the management of livestock density and rations, and to the renovation rate of capital inputs and facilities.

In farming methods articles, researchers' interest is largely directed towards the trade-offs between conventional vs. organic and intensive vs. extensive farming.

Authors dealing with genetic resources propose interventions to reduce pollution via the selection of crop cultivars and livestock breeds. The aim is to replace high-impact with low-impact species (e.g., with higher feed conversion potential) or the substitution of animal with plant protein sources.

Health and ethics is the only category within the social dimension of sustainability. Interventions involve the evaluation of different dietary patterns that combine impact reduction with improved consumer health or, more simply, with diet ability to allow nutrition security. Ethical issues include animal welfare, the delivery of ecosystem services, and researchers' perspective on the selection of the impact assessment method for their LCA.

Sustainable intensification articles evaluate potential strategies to increase the productivity of current agricultural systems. Studied actions mainly involve varying consumable inputs, and field operations. Consumable inputs are generally nitrogen fertilizers and livestock feed. Field operations include types of tillage with different intensities (reduced tillage, no-tillage, standard tillage) and are not assessed per se, but as complements of fertilizer management options.

Supply chain management interventions target logistics aspects, such as the selection of farming locations (or food origin for demand-side approaches) based on the location of the target market, pedoclimatic characteristics, the availability of processing facilities in the neighborhoods, the type of available transportation roads and the means of transport.

Processing methods are not addressed as stand-alone interventions, but as complementary approaches to mitigate the impacts of food production.

Water supply involves the design or rules for the effective management of underground and surface water for crop irrigation at the territorial level.

Interventions to promote waste circularization aim at adding value to agricultural residues and waste, largely thanks to the production of bioenergy, besides a reduction in the environmental externalities of agricultural and food systems on the environment. Recovering energy and fertilizer potential from livestock waste and the creation of bio-based supply chains offer cost-effective burden mitigation opportunities. 


\subsection{Conceptualisation of Interventions and Usefulness in Policy Making}

Most articles address impact mitigation from the supply side, focusing on actions taken by private businesses at the process level, while government and research-level perspectives are minor (Figure 3a). Research objectives are many, e.g., hot-spot identification, hot-spot association with farm structure and management, and mitigation opportunities via technology adoption. Demand-side approaches are still reduced and mainly imply decision-making by the public, concerned with the prospected mitigation of the environmental impacts via the reduction in the consumption of animal-based products, especially ruminant meat from extensive livestock husbandry, with minimal effects on nutrition security. Demand-side approaches focus on countries where the consumption of animal-based products is deeply rooted and is a significant component of agricultural systems, while overlooking the most fast-growing countries. More research relying on demand-side approaches is needed for developing countries, especially where the consumption of animal-based products has recently boomed due to welfare and population increase. Ethical perspectives have not received great attention thus far. System-level approaches are the least frequent ones, requiring the collaboration of supply and demand-side stakeholders to allow the redesign of the current patterns of food production and consumption.
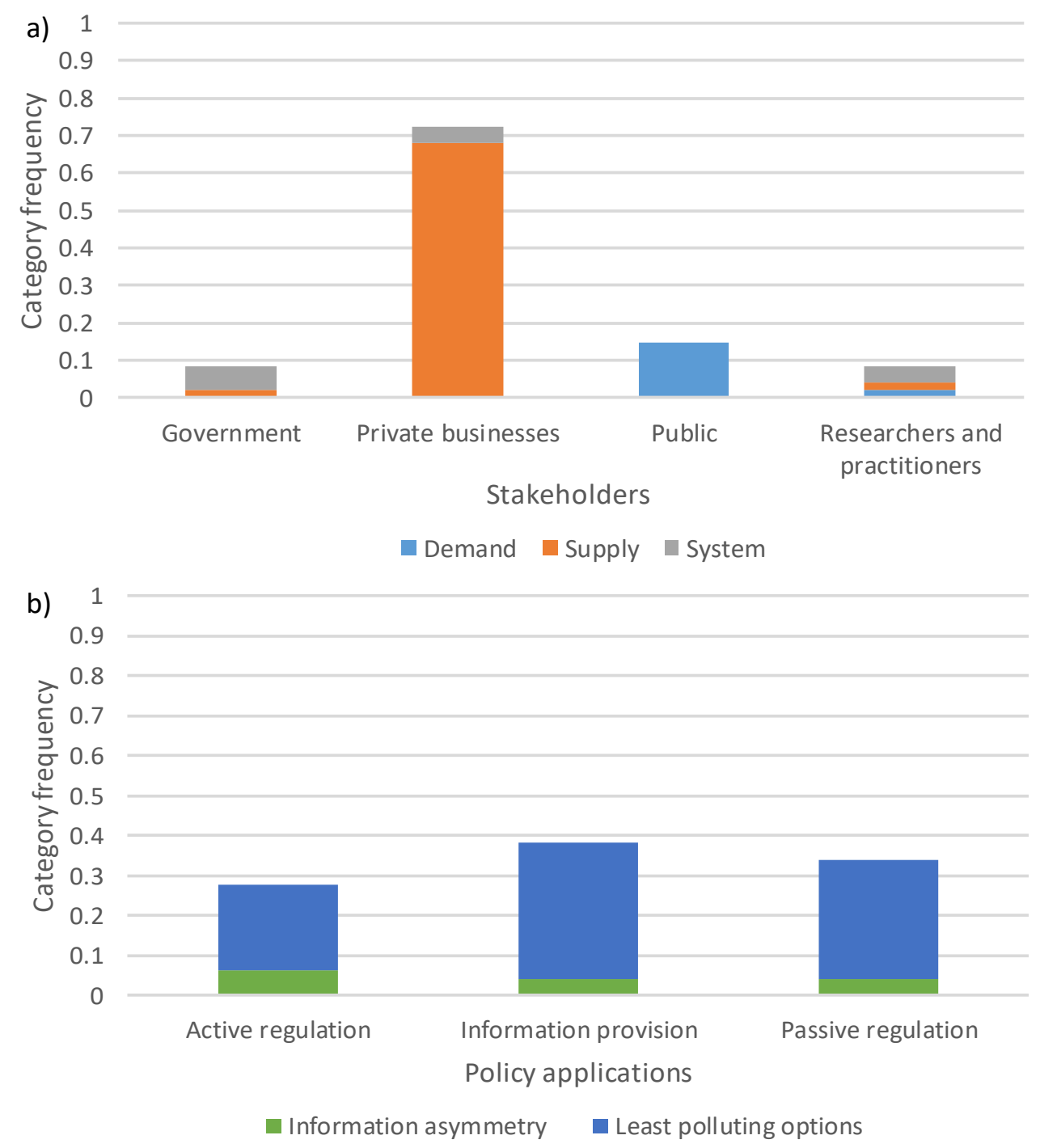

Figure 3. (a) Intervention conceptualization and prospected executors. (b). Usefulness of LCA-based information in policy making. Source: authors' own elaboration. 
The information delivered by the largest share of articles is of practical usefulness for policy makers dealing with the adoption of the least polluting options (Figure 3b). Policy makers working on the reduction in information asymmetry from business-to-consumer may also benefit from the retrieved research. Information provision is the preferred policy application for promoting the least impactful options and actions to reduce information asymmetry, followed in order by passive and active regulation. Moving to passive regulation, the more common comparison is organic vs. conventional farming. The literature is very varied in terms of compared management and/or technological options, with different options being often combined within single studies. Compared to information provision and active regulation, the literature in support of active regulation is a little narrower.

\subsection{Types of LCA and Delivery of Multidimensional Assessments}

Figure 4 shows the diffusion of different approaches to LCA in the analyzed literature (Figure 4a) and the addressed dimensions of sustainability (Figure $4 \mathrm{~b}$ ).

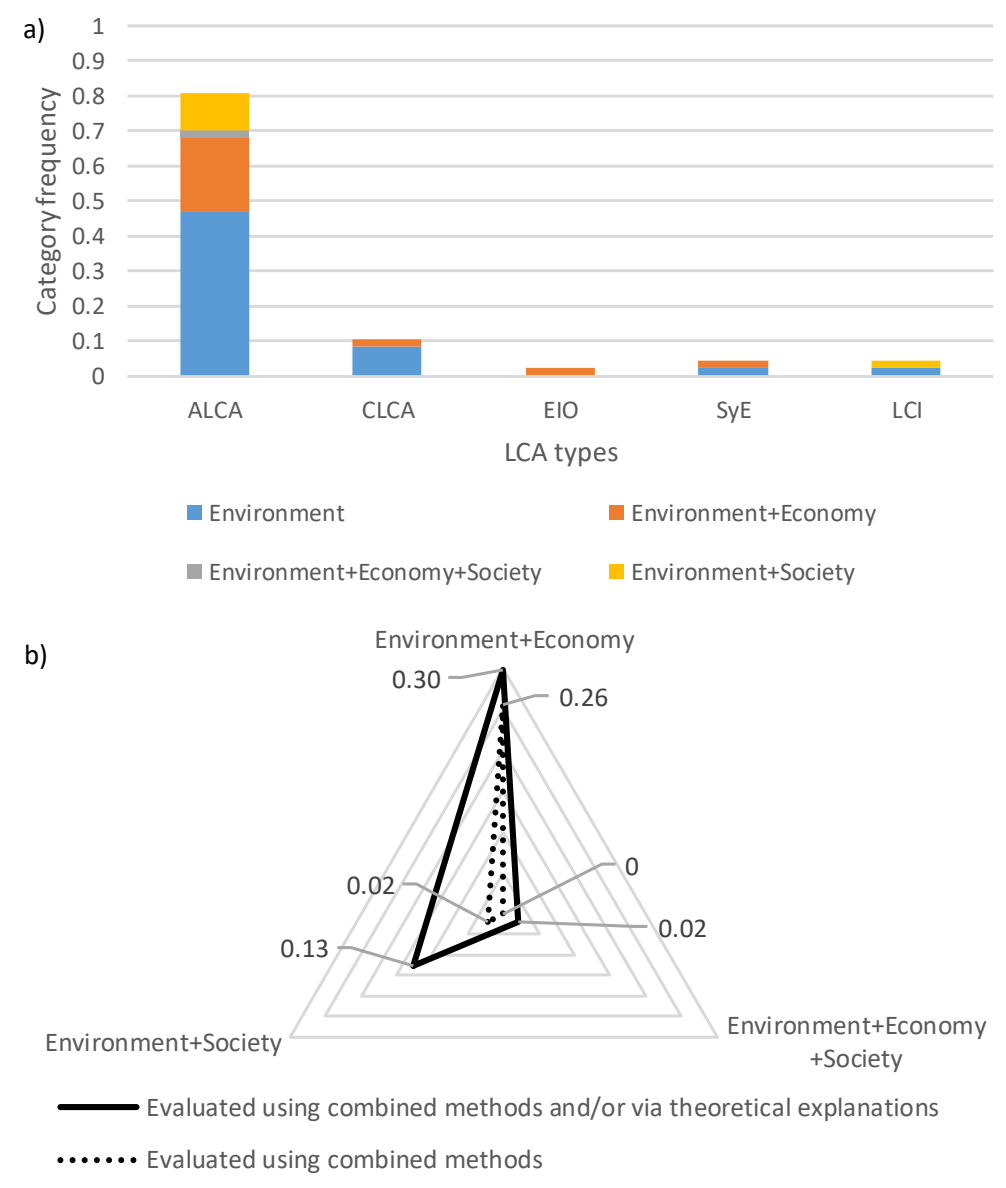

Figure 4. (a) Types of LCAs and addressed sustainability dimensions. ALCA: Attributional LCA (including carbon footprint, literature reviews); CLCA: Consequential LCA (including literature reviews, theoretical analysis); EIO: Environmental input-output LCA; SyE: LCA with system expansion; LCI: Life cycle inventory. (b) Relationship between the addressed dimensions of sustainability (solid line) and those dimensions addressed using multidimensional methods (dotted line), in terms of category frequencies. Source: authors' own elaboration.

The attributional framework is the preferred computational approach. More studies in food economics and policy research should adopt the consequential framework, given its ability to link environmental and economic aspects associated with the adoption and diffusion of impact-mitigating interventions and the possibility of modelling rebound effects. Less than half of the analyzed articles 
cover more than one (environmental) dimension of sustainability. The most common combination is environmental-economic, followed by environmental-social and environmental-economic-social. Multidimensional assessments either rely on the implementation of multiple methodologies, with shared data needs, or on theoretical explanations. The former mainly combine environmental and economic assessments, the latter environmental and social assessments. A greater development and research use of social impact assessments is needed, as consumers are often not ready or educated enough to accept radical changes in food production methods. Studies relying on consequential assessments are still few and a single article proposes a hybrid EIO-LCA. Two articles stop at the life cycle inventory phase and use the outputs for combined assessments. Qualitative (theoretical) evaluation is also applied to integrate environmental with economic or social aspects. Most combined methodological frameworks rely on the ALCA (including carbon footprint).

\subsection{Recommendations about Rebound Effect Modelling}

All articles provide general and/or case-specific recommendations for further research, but just a third of them focus on the rebound effects associated with the implementation of the proposed impact-mitigating interventions. Generally, authors addressing REs do not concentrate on single categories, but rather offer suggestions for effect combinations.

Articles providing insights into direct REs focus on feasible changes in the production and/or consumption of one or more products under study by improving product competitiveness on the market. Direct REs reinforce the contribution of an intervention. Private businesses may find it profitable to implement impact-mitigating interventions. Examples include the mitigation of food's life cycle impacts via breeding programs to reduce yield losses, the use of wearable sensors for monitoring animal health and reducing production costs or the adoption of sustainability certification and labelling schemes to increase the value added per unit product.

Indirect REs balance the overall impact of interventions. Indirect REs are associated with burden shifts among production processes, changes in the demand for inputs to food or energy production inputs and for foodstuffs, and with substitution effects. Dietary change scenarios may shift the environmental burden across livestock farming systems or from livestock to crop farming systems. The adoption of more eco-friendly farming methods drives an increase in the demand for consumable and capital inputs that enable emission reduction. The policy-driven implementation of territorial-level interventions to add value to agricultural waste decreases the demand for energy from conventional sources. The premium price associated with environmental certifications and labelling schemes increases the consumer price for a given foodstuff, which affects the supply and demand of its substitutes. At the territorial level, this may lead to shocks in the price and in the price elasticity of demand of the foodstuff and its substitutes.

The implementation of impact-mitigating interventions at the territorial (e.g., national, subnational) level affects multiple economic sectors, thereby originating economy-wide REs. Those REs involve the market responses to large-scale and radical changes in the supply and demand of food and bio-based products. Those (simulated) responses involve the potential shutdown of energy plants after the diffusion of waste-to-energy plants and the increased profitability of agriculture due to the diffusion of biorefineries, land and water use change from food/feed to energy production, and the government's adoption of measures for spatial and resource use planning, including land sparing. Besides CLCAs, REs can be addressed by integrating multiple dimensions of sustainability (environmental, economic, social) in a single research and/or by increasing stakeholder participation in the assessment [29], as, for example, in the study of [95]. Authors evaluated the environmental impact of decision-making about water supply planning. The most studied interventions address the selection of farming methods and genetic resources, and the improvement in production management.

A last strand of literature reports on the prospected societal changes conditional on the adoption and diffusion of interventions to reduce the environmental impacts of agricultural products, namely transformational REs. In practice, those REs are due to, e.g., the diffusion of new dietary guidelines, 
the availability of certified or labelled foods, or the introduction of foods produced using innovative methods. The growing concerns about health and the increasing demand for convenience foods drive changes in consumers' behavior. The latter should be supported by a reduction in information asymmetry from business-to-consumer, e.g., via sustainability labelling. However, consumers might be averse to innovative food production, e.g., involving feeding livestock with food waste, or food packaging methods, such as plastic bottles for wine, thereby increasing the production of waste throughout the supply chain.

\subsection{Relationships among Themes and Interventions}

Figure 5a,b show the diagrams of the "stakeholder involvement for sustainability" and "method selection for policy application" relationships, respectively. Table 5 displays node-level metrics. Intervention clusters are available in Table A4.

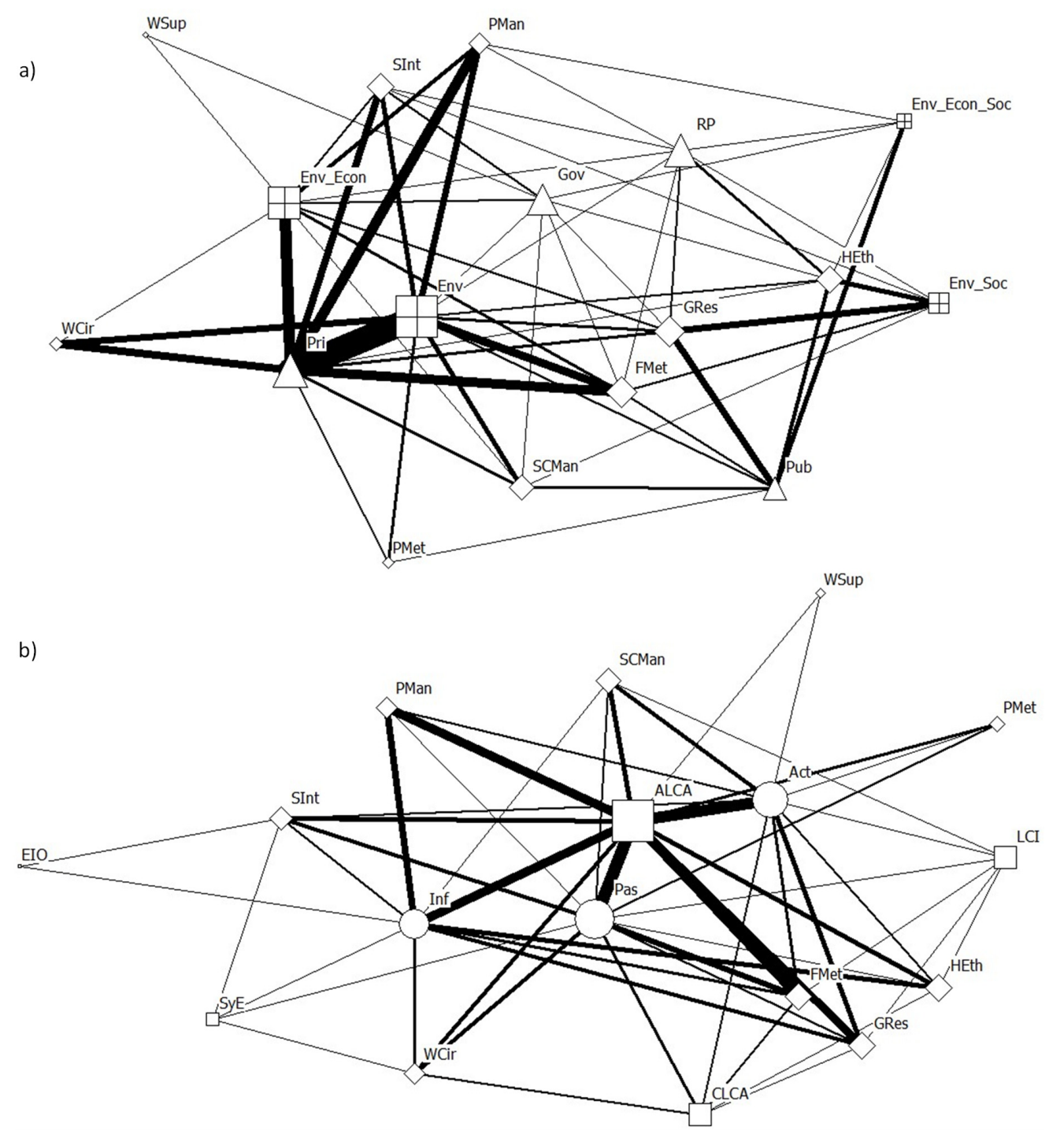

Figure 5. (a) Stakeholder involvement for sustainability: triangles are stakeholders; boxes are sustainability dimensions; diamonds are interventions. (b) Method selection for policy applications: circles are policy applications; squares are methods, i.e., LCA types; diamonds are interventions. Node sizes are proportional to their eigenvector centrality; tie width is proportional to tie strength. Source: authors' own elaboration using Ucinet@ software [108]. 
Table 5. Eigenvector centrality of network nodes. Figure 4. Source: authors' own elaboration.

\begin{tabular}{|c|c|c|c|}
\hline \multirow{2}{*}{ Node } & \multirow{2}{*}{ Description } & \multicolumn{2}{|c|}{ Eigenvector Centrality } \\
\hline & & Figure $5 a$ & Figure $5 b$ \\
\hline FMet & Farming method & 0.38 & 0.35 \\
\hline GRes & Genetic resources & 0.38 & 0.35 \\
\hline PMan & Production management & 0.27 & 0.27 \\
\hline HEth & Health and ethics & 0.35 & 0.35 \\
\hline SInt & Sustainable intensification & 0.33 & 0.31 \\
\hline SCMan & Supply chain management & 0.32 & 0.31 \\
\hline WCir & Waste circularization & 0.19 & 0.27 \\
\hline PMet & Processing method & 0.17 & 0.21 \\
\hline WSup & Water supply & 0.11 & 0.14 \\
\hline Pri & Private businesses & 0.44 & - \\
\hline Gov & Government & 0.41 & - \\
\hline Pub & Public & 0.31 & - \\
\hline $\mathrm{RP}$ & Researchers and practitioners & 0.42 & - \\
\hline Env & Environmental assessments & 0.53 & - \\
\hline Env_Econ & $\begin{array}{c}\text { Combined environmental-economic } \\
\text { assessment }\end{array}$ & 0.43 & - \\
\hline Env_Soc & $\begin{array}{l}\text { Combined environmental-social } \\
\text { assessment }\end{array}$ & 0.29 & - \\
\hline Env_Econ_Soc & $\begin{array}{c}\text { Combined } \\
\text { environmental-economic-social } \\
\text { assessment }\end{array}$ & 0.23 & - \\
\hline Inf & Information provision & - & 0.42 \\
\hline Pas & Passive regulation & - & 0.52 \\
\hline Act & Active regulation & - & 0.47 \\
\hline ALCA & $\begin{array}{l}\text { Attributional LCA (including carbon } \\
\text { footprint, literature reviews) }\end{array}$ & - & 0.54 \\
\hline CLCA & $\begin{array}{c}\text { CLCA (including literature reviews, } \\
\text { theoretical analysis) }\end{array}$ & - & 0.32 \\
\hline EIO & Environmental input-output LCA & - & 0.10 \\
\hline SyE & LCA with system expansion, & - & 0.21 \\
\hline $\mathrm{LCI}$ & Life cycle inventory & - & 0.27 \\
\hline
\end{tabular}

In the "stakeholder involvement for sustainability" network, the greatest flow density occurs towards the link between private businesses (mainly farmers) and environmental assessments. Studies about the way to mitigate the environmental burden of farming methods largely contribute to this flow, together with those addressing production management. Combined economic-environmental assessments are strongly linked with private businesses, as well. The flow of information generated by the environmental assessment of the adoption of waste circularization strategies on farm is relatively large, despite the very low eigenvector centrality of waste circularization strategies. This suggests that researchers' interest in the category is still strongly linked with environmental impacts and studies with a wider scope are needed, dealing, e.g., with territorial interventions promoted by governments and supported by researchers and practitioners. Processing method and water supply show the lowest centrality. The latter shows the weakest link pattern within the network. This 
identifies water supply as an understudied intervention; especially, more research is needed about the adoption of different water management systems by private businesses and the public. The role of the government and practitioners should be strengthened, via the design of cost-effective spatial planning strategies. Processing methods need more attention, as well, especially covering the economic and social dimensions and addressing the role of private and institutional stakeholders, and of researchers and practitioners. However, public (consumers) concern about food choices has raised, probably due to a greater awareness about information asymmetry from business to consumer, which has increased consumers' willingness to pay for labelled food.

As expected, the "method selection for policy applications" network is centered towards ALCA, i.e., the oldest and most widespread type of LCA. The strengths of ALCA links with passive and active regulation are similar. The centralities of passive and active regulation are close to each other and greater to that of information provision. This pattern may be the result of the reduced evaluation of experimental technologies. The retrieved literature is concerned with the adoption of technologies available on the market, with technical details about the process already known by policy makers. More interdisciplinary and transdisciplinary collaborations across research fields (e.g., chemistry, engineering, economics) might boost information provision about innovative technologies, e.g., via pilot farm testing. Additionally, this might help the diffusion of EIO studies at the national level over multiple time periods. To date, the method has been rarely used in the retrieved literature; however, it offers great potential for addressing the role of institutional, private businesses and the public in economy-wide interventions. The largest information flow occurs between ALCA and farming method interventions, followed by production management. Genetic resources, sustainable intensification, supply chain management and health and ethics are rather strongly linked with ALCA and all policy applications. Given the purpose of CLCAs, information provision is not among the study aims. Consequential studies can focus on the interaction between multiple categories of interventions by evaluating rebound effects. Farming method is combined with waste circularization, genetic resources and health and ethics, while supply chain management, processing method, sustainable intensification and water supply are disregarded. Especially, the rebound effects associated with the adoption of sustainable intensification and different types of water supply management are key missing items in the retrieved consequential studies. Despite being partial assessments, LCIs greatly benefit the environmental and agricultural economics literature by providing evidence about the inputs and outputs of a variety of processes at different geographical scales. Researchers tend to provide complete LCAs. However, more LCIs are needed to deliver key information to policy makers, for emissions at different spatial scales and points in time about alternative production management, sustainable intensification, processing methods, water supply and waste circularization interventions.

\section{Conclusions}

\subsection{Key Findings}

Coherently with [21], the present research has highlighted that supply-side approaches show the greatest diffusion, demand-side approaches are less widespread and system-level approaches are very few. Private businesses are the preferential targets of supply-side approaches. The attention towards waste circularization strategies has grown, by estimating the impact-mitigating potential of the recovery of energy, fertilizers or new raw materials from agricultural and food waste. Demand-side approaches target the consumption of animal-based products, given the recognized pollution potential of livestock husbandry, especially when animals are reared in extensive systems [24,109]. System-level approaches are still few and need more attention by the research community [21]. Governments are key to allowing the large-scale adoption of systemic interventions and to supporting research activities to monitor the improvements $[110,111]$. The traditional ALCA is by far the preferred computational approach, with CLCAs showing a reduced diffusion. The social impacts of dietary change are addressed just on a theoretical basis, without considering the public acceptability of diets that largely rely on plant-based 
products, including the introduction of meat substitutes and the use of food supplements. Some of the articles included in this research suggest considering the potential changes in the production or consumption of a given product (direct rebound effects) or of their substitutes (indirect rebound effects) after the adoption of low-impact farming, improved seed varieties, innovative technologies, or process certifications and environmental labelling. Importantly, a relevant share of authors focus on broader effects (economy-wide rebound effects) or on societal response (transformational rebound effects) associated with the large-scale implementation of interventions to reduce the impact of food or commodity production.

\subsection{Policy Implications and Recommendations}

A series of policy options and market incentives are available for decision makers willing to implement environmentally friendly interventions, targeting the demand and supply of food. Market incentives are largely related to farmers' adoption of environmental certifications and labelling schemes that grant the product a premium price and can combine supply-side with demand-side interventions [112,113]. Instead, policies are more oriented towards the regulation of primary production only. For example, in the EU, environmental rules of the Common Agricultural Policy support low-impact farming with a combination of mandatory and voluntary instruments, such as the "greening" payment delivered to farmers implementing practices beneficial for the climate and the environment, agri-environment-climate measures or cross-compliance under the direct payment pillar. The objectives of the prospective post-2020 reform of the Common Agricultural Policy call for even greater involvement of farmers in the climate change challenge and in the provision of heathy and sustainable food, while aiming at production efficiency. Different approaches to impact mitigation exist with multidimensional objectives, which do not seem fully endorsed by the current post-2020 proposal [114]. Effective interventions to reduce the impact of the food system and contribute to the achievement of SDGs would require a different and more holistic approach to policy design via a renovated policy mix [115] or mission-oriented policies [116] that targets both the supply and demand sides [117].

The promotion of renewable energy portfolio standards worldwide has supported the diffusion of distributed energy models in rural areas, which offer a viable way to raise the share of bioenergy in the domestic energy mix $[118,119]$. The adoption of farm-based or collective waste-to-energy or waste-to-fertilizer plants can benefit from investment incentives from public policy frameworks (e.g., from the Rural Development Program of EU's Common Agricultural policy). Policy makers and researchers should concentrate on the acceptability of new dietary guidelines and alternative management practices in livestock husbandry by the public $[25,120]$, on the improvement of label communicativeness [121], as well as on the design and implementation of information and education campaigns for raising consumer awareness and responsibility [122,123]. The implementation of evidence-based policy needs updated information from comprehensive impact assessment studies and scenario analyses, to reduce the uncertainties in policy design and to avoid the tradeoffs among objectives. This is especially important for the design of food policy, which is often affected by information failure [124]. Adopting a system thinking approach in the conceptualization of interventions might help address multiple dimensions of sustainability at the same time, by creating synergies among supply chains and stakeholders. This would allow more attention to be paid to intermediate steps of the supply chain and to supply chain management options, as well as to the social acceptability of interventions. The existence of multiple interacting elements makes monitoring the impacts of those interventions on the environment, economy and society a complex task. That complexity is inversely related to the geographical proximity of food systems. The type and intensity of rebound effects (and of the related model assumptions) grows with system boundaries [125]. The success of system-level interventions depends on stakeholder communication and collaboration, which may be difficult to achieve. In this respect, policy-makers may facilitate the creation and stabilization of connections among different stakeholders and may help product acceptability by the public via 
dedicated educational services, as, for example, in the case of the short supply chain projects funded by the Rural Development pillar of EU's Common Agricultural Policy (Reg (EU) 1305/2013) or the European Innovation Partnership "Agricultural productivity and Sustainability" of European Commission (COM (2012) 79 final). Further research can inform agricultural policy planning by providing evidence from existing system-level approaches to impact mitigation, to highlight their impact-mitigating potential and the observed rebound effects on related systems, and to pinpoint the drivers and barriers of adoption of effective interventions. Especially, countries with the greatest expected population and urbanization growth need more attention from researchers for effective policy making towards agricultural sustainability and food security worldwide.

Author Contributions: Conceptualization, O.G.; investigation, O.G., F.B. and F.V.; writing-original draft preparation, O.G.; writing-review and editing, O.G., F.B. and F.V.; supervision, G.B. and A.P.; project administration, G.B. and A.P.; funding acquisition, G.B. and A.P. All authors have read and agreed to the published version of the manuscript.

Funding: This research was funded by the University of Pisa, project SALI (Strumenti di sostenibilità delle produzioni alimentari, Sustainability tools for food production) code PRA_2017_34. 583.

Acknowledgments: Authors thank Michael MacLeod, from Scotland's Rural College, and Mikaela Lindberg, from the Swedish University of Agricultural Sciences, for sharing information about their research.

Conflicts of Interest: The authors declare no conflict of interest. The funder had no role in the design of the study; in the collection, analyses, or interpretation of data; in the writing of the manuscript, or in the decision to publish the results.

\section{Appendix A}

Table A1. List of journals for Scopus' search. The W superscript indicates items included in WOS-AEP, as well. Source: Authors' own elaboration.

\begin{tabular}{|c|c|}
\hline Agricultural Economics $W$ & Food Policy ${ }^{W}$ \\
\hline American Journal of Agricultural Economics W & Journal of Agricultural and Resource Economics W \\
\hline Applied Economics & Journal of Agricultural Economics W \\
\hline $\begin{array}{l}\text { Australian Journal of Agricultural \& Resource } \\
\text { Economics W }\end{array}$ & Journal of Environmental Economics \& Management \\
\hline Ecological Economics & Journal of Environmental Management \\
\hline Economics Letters & Land Economics \\
\hline Environmental and Resource Economics & Review of Economics and Statistics \\
\hline European Review of Agricultural Economics W & World Bank Economic Review \\
\hline
\end{tabular}


Appendix A.1 Description of the Retrieved Material

Table A2. Formal aspects of the material under study. The number of articles of top three categories is displayed in parentheses. Source: Authors' own elaboration.

\begin{tabular}{|c|c|}
\hline Article Feature & Description \\
\hline Open access & No (46); Yes (1) \\
\hline Funding body & $\begin{array}{l}\text { Consortium of public/private research org.; National government/local administration (11); } \\
\text { Grant-making foundation (7); Industry; Public research/extension org. (9); private research org.; } \\
\text { Producers organization; Retail; Supranational org.; University }\end{array}$ \\
\hline Research type & Original (44); Review (2); Theoretical analysis (1) \\
\hline Scope & National (17); Subnational (15); Case study (12), not classifiable \\
\hline Sector & $\begin{array}{l}\text { Agri-food (8); Aquaculture; Meat (10); Cereal, oilseed, protein (8); Dairy (14); Processed items; } \\
\text { Starchy, sugar crops; Wine }\end{array}$ \\
\hline Country codes & BE; BR; CH; CN; DE; DK; ES; FR; IE; IR; IT (10); JP; NL; NZ; SE (4); TH; TR; UG; UK; US (5) \\
\hline Data sources & $\begin{array}{l}\text { Primary (questionnaires + industry/farmers' cooperatives/research centres) (30); Official statistics } \\
\text { and government reports (31); Scientific and grey literature; LCI databases: Agrifootprint, APME, } \\
\text { Dia'terre, Ecoinvent (21), ELCD, ETH-ESU, GaBi, GEMIS, IDEMAT, LCA food, ProBas, SALCA, } \\
\text { USDA LCI; Other databases and reports: FAOSTAT, HI-Animal, Mecacost, university databases, } \\
\text { USEPA }\end{array}$ \\
\hline System boundaries & $\begin{array}{l}\text { Cradle-to-consumption; Cradle-to-distribution hubs (5); Cradle-to-gate (25); Cradle-to-grave (4); } \\
\text { Cradle-to-retail; Gate-to-grave (5) }\end{array}$ \\
\hline Functional unit & Area (9); Energy (3); Production unit; Sale receipts; Volume; Weight (39) \\
\hline $\begin{array}{l}\text { Treatment of multifunctional } \\
\text { processes }\end{array}$ & $\begin{array}{l}\text { Mass (8); Feed requirements: quantity, proteins or energy; Energy; Emergy; Economic (7); } \\
\text { Ecosystem services; Proteins; System expansion; Unspecified physical property (7); No method } \\
\text { specified (9) }\end{array}$ \\
\hline Impacts assessed & AP (22); BD; CE; ED; EP (26); ET; FFD; GWP (47); HT; IR; LU; MRD; NPPU; OD; RE; POF; WC; WD \\
\hline Uncertainty & Technical literature (2); Sensitivity analysis (9); Monte Carlo (4); Pedigree matrix; Averaged values \\
\hline Variability & Time (5); Space (5); Not addressed (37) \\
\hline Data issues (highlighted) & $\begin{array}{l}\text { Information gaps due to missing real world (3), up to date (3), location-specific (2), animal welfare } \\
\text { data; Missing features of LCI databases: spatial differentiation, alternatives to mainstream foods } \\
\text { (3), extensive farming systems, soil loss, phosphate waterborne emissions, carbon storage potential } \\
\text { of farming systems }\end{array}$ \\
\hline \multicolumn{2}{|c|}{$\begin{array}{l}\text { Note: AP: acidification potential; BD: biological resource depletion; CE: carcinogenic effects; ED: energy demand; } \\
\text { EP: eutrophication potential; ET: ecosystem toxicity; FFD: fossil fuel depletion; GWP: global warming potential, HT: } \\
\text { human toxicity; IR, LU: land use; MRD: mineral resource depletion; NPPU: net primary production use; OD: ozone } \\
\text { depletion potential; RE: respiratory effects; POF: photochemical oxidant formation; WC: waste creation; WD: water } \\
\text { depletion. The denomination of impact categories may vary based on the LCA calculation method. Here, we used a } \\
\text { common nomenclature, which does not necessarily mirror the one used in the original study, and, in some cases, we } \\
\text { grouped impact categories to avoid an overflow of information, provided that discussing about the selection of } \\
\text { impact categories and impact assessment methods are beyond the scope of this article. }\end{array}$} \\
\hline
\end{tabular}

Most documents report on original LCA-based research. Among the three non-original researches, [81] offers a theoretical analysis of rebound effects, to help their inclusion into CLCA modelling; [70] review refereed and non-refereed LCA studies about protein-sourcing foods (including meat substitutes) to highlight major sources of impact and opportunities for mitigation, based on genetic resources (animal vs. plant; species) and production practices (growing or catching systems); [86] review refereed ALCA and CLCA studies that compare the impacts of conventional vs. organic agriculture across different sectors. Similar shares of assessments are carried out at national, subnational or case study levels. All populated world regions are represented (especially North America), but most studies are set in Europe (especially in Italy and Sweden).

The single most studied agricultural sector is dairy farming, though livestock husbandry is a popular object of analysis, especially when producing meat. Animal-based products are followed by the cereal, oilseed and protein sector, with rice farming being the most investigated cropping system and non-food crops being almost disregarded: just [78] delivers an LCA of sunflower seed for biofuel conversion.

Global warming potential is the most widespread impact assessment category among authors and is often supplemented with estimates about acidification and eutrophication potential. The studies 
generally focus on the production phases, with around $60 \%$ of studied delivering cradle-to gate impacts. The remainder $40 \%$ of articles have wider boundaries, including different transportation (and storage) steps. Of those articles, five carry out cradle-to-grave assessments. Weight-based functional units are by far the most used, followed by area-based units. Moving to the treatment of multifunctional processes, most attributional studies allocate product emissions based on physical properties. Economic allocation has a lower diffusion. Mass is most popular among physical properties; other properties, e.g., feed requirements, energy consumption, and energy or protein content, are less widespread. A significant share of studies do not specify the type of physical property or do not consider process multifunctionality. Besides consequential assessments, just two articles adopt the system expansion framework. However, that method shows a wider diffusion, because some assessments compare the impacts associated with the use of different approaches for the treatment of multifunctional processes vs. the decision of not considering process multifunctionality. [87] adds an own-developed set of rules for allocating emissions based on the monetary incentives received by farmers for adopting management practices beneficial to the environment.

Primary data originate from interviews and/or surveys of farmers (mainly), stakeholders of downstream chain phases (food industry, food logistics, retailers), and even stakeholders in the fields of research and extension services. Though primary data should be the gold standard, researchers and practitioners may need to rely on secondary data, especially in the case of assessments over large areas, which make the costs of collection of farm-level data for LCA purposes unaffordable [101]. Secondary data are gathered from different sources, such as official statistics and reports, university reports and databases, business databases, and published LCA studies. Even those data may not satisfy specific research needs. For example, from the literature on dietary change, a lack of information emerges about non-mainstream livestock species or breeds and innovative meat substitutes (e.g., [70]); other authors have detected the need for more real-world information about innovative processing technologies (e.g., [68]). LCI databases are used to bridge data gaps and to gather information about background processes (e.g., the production of agricultural inputs), though some authors entirely rely on them (e.g., [91]). Despite being essential data sources, LCI databases are not perfect. A large share of authors highlight data issues, mainly due to gaps (e.g., missing information about real-world impacts; available data originating from estimates) or a lack of updates. Other areas of required improvements are the spatial and temporal differentiation within datasets and data consistency across databases, to facilitate their combined use. The reliance on diverse data sources makes it difficult to have accurate reference times for LCAs.

The treatment of variability and uncertainty is not uniform across studies. Few researchers address time/space variability, with most of them concentrating on space. $[64,69,73]$ compare the impacts of agricultural systems in different locations. [97] uses a stratified sample of French sheep farms to account for farm location. [101] uses data from multiple locations in southern states of the US. Similarly, [65] combines data from worldwide sources. [82] uses a geographical information system tool for georeferencing farm-level measures. Just two articles include the time component in their research: [72] carries out the assessment over different harvest years; [74] uses 10 year input-output tables. Data referring to different locations and time periods are compared just by the two literature reviews. 


\section{Appendix B}

Table A3. Article membership to structural categories, in chronological order. Sup: Supply; Dem: Demand; Sys: System; Pri: Private businesses; Gov: Government; Pub: Public; RP: Researchers and practitioners; Pol: Least polluting options; Asy: Information asymmetry; Inf: Information provision; Pas: Passive regulation; Act: Active regulation; FMet: Farming method; GRes: Genetic resources; Heth: Health and ethics; Processing method; PMan: Production management; SCMan: Supply chain management; Sint: Sustainable intensification; WCir: Waste circularization; WSup: Water supply; EEMet: Using combined environmental and economic evaluation methods; EEExp: Addressing the economic dimension via theoretical explanations; ESMet: Using combined environmental and social evaluation methods; ESExp: Addressing the social dimension via theoretical explanations; Dir: Direct rebound effects; Ind: Indirect rebound effects; EcW: Economy-wide rebound effects; Tra: Transformational rebound effects. Source: authors' own elaboration.

\begin{tabular}{|c|c|c|c|c|c|c|c|c|c|c|c|c|c|c|c|c|c|c|c|c|c|c|c|c|c|c|c|c|}
\hline \multirow{2}{*}{ Ref } & \multicolumn{7}{|c|}{ Conceptualization and Stakeholders } & \multicolumn{5}{|c|}{ Policy } & \multicolumn{9}{|c|}{ Interventions } & \multicolumn{4}{|c|}{ Evaluated Dimensions } & \multicolumn{3}{|c|}{ Rebound Effects } \\
\hline & Sup & Dem & Sys & Pri & Gov & $P u b$ & $R P$ & Pol & Asy & Inf & Pas & Act & FMet & GRes & Heth & PMet & PMan & SCMan & SInt & WCir & WSup & EEMet & EEExp & ESMet & ESExp & Dir & Ind & $E c W \operatorname{Tra}$ \\
\hline [56] & & - & & & & & - & & & - & & & & - & & - & & & & - & & & & - & & & & \\
\hline [57] & • & & & & • & & & & & & 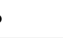 & & - & & & & & & & - & & & & & - & & & \\
\hline [58] & • & & & - & & & & & • & & & & - & & - & & & & & & & & & & & & & - \\
\hline [59] & • & & & & $\bullet$ & & & & & $\bullet$ & & & $\bullet$ & & & & & & & & $\bullet$ & & & $\bullet$ & & & & \\
\hline [60] & $\bullet$ & & & & $\bullet$ & & & & & $\bullet$ & & & $\bullet$ & & $\bullet$ & & & $\bullet$ & & & & & & $\bullet$ & & & & \\
\hline [61] & - & & & - & & & & & • & & - & & & & & & & - & & & & & - & & & & & - \\
\hline [62] & $\bullet$ & & & & $\bullet$ & & & & $\bullet$ & & $\bullet$ & & & & & & & $\bullet$ & & & & & $\bullet$ & & & & & \\
\hline [63] & • & & & $\cdot$ & & & & & $\cdot$ & & & $\cdot$ & & & & & & & & & - & & - & & & & & \\
\hline [64] & • & & & & $\bullet$ & & & & & & 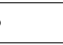 & & & $\bullet$ & & & & & & & $\bullet$ & $\bullet$ & & & $\bullet$ & & & \\
\hline [65] & & - & & & & - & - & & & & - & - & & & & - & - & & & - & & & & & & & & - \\
\hline [66] & & $\bullet$ & & & & $\bullet$ & $\bullet$ & & & $\bullet$ & & & & $\bullet$ & $\bullet$ & $\bullet$ & $\bullet$ & & & & & & & $\bullet$ & & & & \\
\hline [67] & $\bullet$ & & & & $\bullet$ & & & & & & & $\bullet$ & & $\bullet$ & & $\bullet$ & & & & $\bullet$ & & & & & $\bullet$ & & & \\
\hline [68] & • & & & & $\bullet$ & & & & $\bullet$ & & $\bullet$ & & & & & & & & & & $\bullet$ & & $\bullet$ & & & & & \\
\hline [69] & • & & & $\bullet$ & & & & & & $\bullet$ & & & $\bullet$ & $\bullet$ & & & & & $\bullet$ & & & & $\bullet$ & & & & & $\bullet$ \\
\hline [70] & & $\bullet$ & & & & $\bullet$ & $\bullet$ & & & $\bullet$ & & $\bullet$ & & & $\bullet$ & $\bullet$ & & & & & & & & $\bullet$ & & & & \\
\hline [71] & & $\bullet$ & & & & & $\bullet$ & & & & 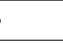 & & & $\bullet$ & & & $\bullet$ & $\bullet$ & & & & & & & $\bullet$ & & & \\
\hline [72] & $\bullet$ & & & $\bullet$ & & & & & & & 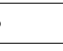 & $\bullet$ & & & & & & & $\bullet$ & & & & & $\bullet$ & & & & \\
\hline [73] & • & & & - & & & & - & & & & - & & - & & & - & & - & & & & - & & & & & \\
\hline [74] & & & - & - & - & & & & • & & & & - & & & & & & & - & & & & & & - & & - \\
\hline
\end{tabular}


Table A3. Cont.

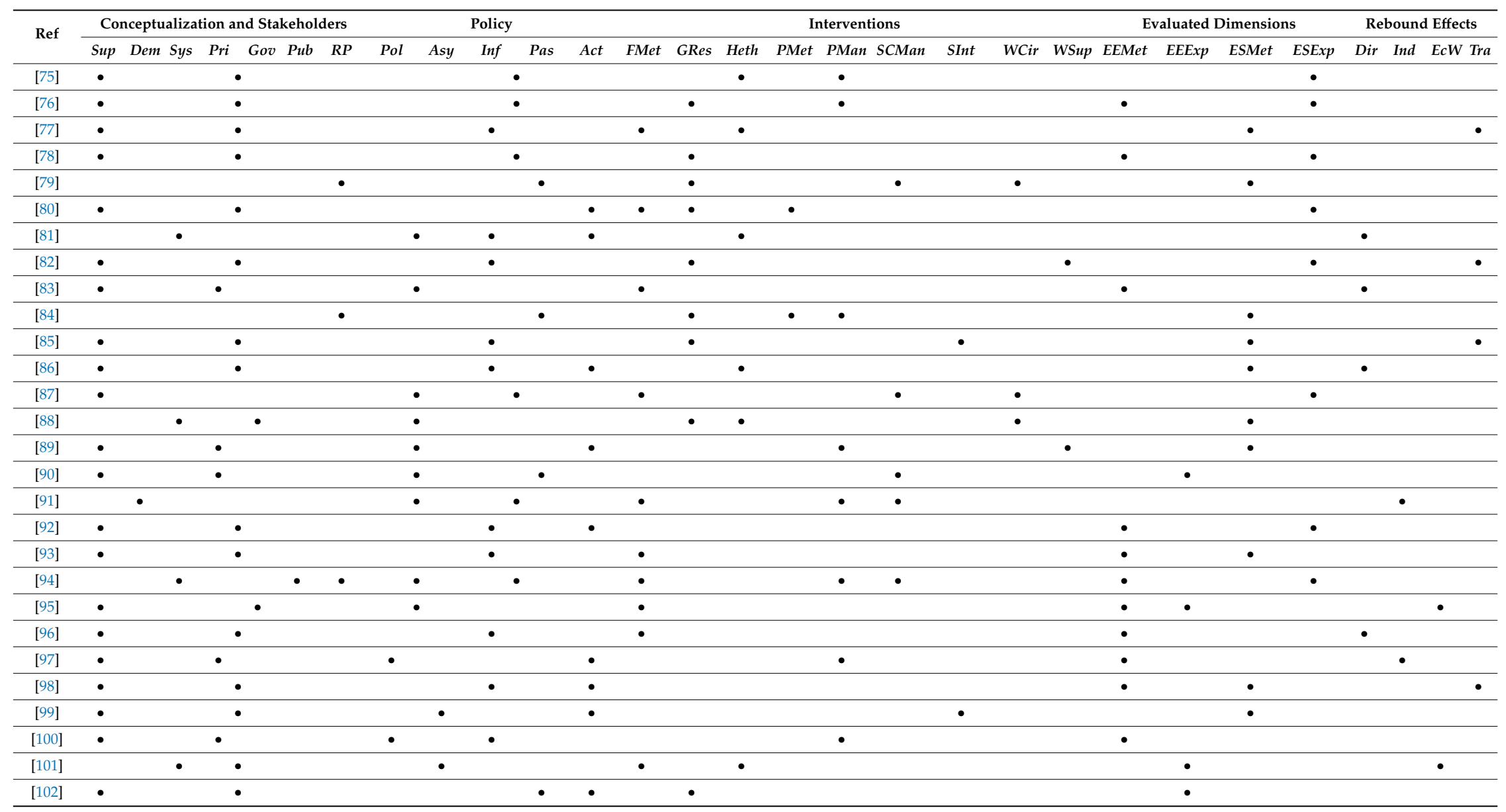


Table A4. Intervention clusters: article owing to each analytic category and category description in terms of structural categories. See Table 4 for the list of codes. Sup: Supply; Dem: Demand; Sys: System; Pri: Private businesses; Gov: Government; Pub: Public; RP: Researchers and practitioners; Pol: Least polluting options; Asy: Information asymmetry; Inf: Information provision; Pas: Passive regulation; Act: Active regulation; FMet: Farming method; GRes: Genetic resources; Heth: Health and ethics; Processing method; PMan: Production management; SCMan: Supply chain management; Sint: Sustainable intensification; WCir: Waste circularization; WSup: Water supply; ALCA: Attributional LCA (including carbon footprint, literature reviews); CLCA: Consequential LCA (including literature reviews, theoretical analysis); EIO: Environmental input-output LCA; SyE: LCA with system expansion; LCI: Life cycle inventory; MMet: Using combined environmental and economic/social evaluation methods; MExp: Addressing the economic/social dimension via theoretical explanations Source: authors' own elaboration.

\begin{tabular}{|c|c|c|c|c|c|c|c|c|c|c|c|c|c|c|c|c|}
\hline \multirow{2}{*}{$\begin{array}{c}\text { Cluster } \\
\text { Intervention }\end{array}$} & \multicolumn{3}{|c|}{ Perspective } & \multicolumn{3}{|c|}{ Stakeholder } & \multicolumn{4}{|c|}{ Policy } & \multicolumn{5}{|c|}{ Methods and Sustainability } & \multirow{2}{*}{ References } \\
\hline & Sup & Dem & Sys & Pri & Gov & $P u b$ & $R P$ & Pol & Asy & Inf & Pas & Act & Research Methods (Number of Articles) & MMet & MExp & \\
\hline FMet & 9 & 2 & 2 & 9 & 1 & 2 & 1 & 10 & 3 & 3 & 7 & 3 & $\begin{array}{l}\text { Theoretical analysis (1); Literature review (2); ALCA } \\
(7+2 \text { incl. LCC); LCI (1) }\end{array}$ & 2 & 3 & {$[58,60,66,67,69,70,73,77,80,81,86,88,102]$} \\
\hline GRes & 2 & 7 & 2 & 3 & 1 & 7 & 2 & 9 & 2 & 4 & 2 & 5 & $\begin{array}{c}\text { Literature review (1); ALCA ( } 5+1 \text { incl. carbon price } \\
\text { premium + } 1 \text { incl. spatial partial equilibrium model + } \\
1 \text { incl. social impacts); CLCA (1); LCI (1) }\end{array}$ & 2 & 5 & {$[56,65,66,70,71,75,76,84,91,94,101]$} \\
\hline HEth & 2 & 4 & 1 & 1 & 1 & 4 & 3 & 5 & 2 & 5 & 1 & 1 & ALCA (5 + 1 incl. social impacts); CLCA (1); LCI (1) & 0 & 5 & {$[65,66,71,84,87,89,91,94]$} \\
\hline PMet & 2 & 1 & 0 & 2 & 0 & 1 & 0 & 2 & 1 & 0 & 2 & 1 & ALCA (3) & 0 & 0 & {$[57,60,61,67,72,85,87,90,97,99,100]$} \\
\hline PMan & 11 & 0 & 0 & 10 & 0 & 0 & 1 & 9 & 2 & 8 & 1 & 2 & $\begin{array}{l}\text { ALCA (6+ } 1 \text { incl. DEA + } 1 \text { incl. full cost accounting + } \\
1 \text { incl. gross value added) }\end{array}$ & 4 & 2 & {$[57,61,62,67,72,85,87,90,97,99,100]$} \\
\hline SInt & 6 & 0 & 2 & 7 & 2 & 1 & 1 & 8 & 0 & 2 & 4 & 2 & $\begin{array}{c}\text { ALCA (5+ } 1 \text { incl. social impacts); EIO-LCA incl. } \\
\text { decomposition analysis (1); LCA sys exp incl. linear } \\
\text { programming (1) }\end{array}$ & 2 & 0 & {$[59,64,74,76,78,82,89,94]$} \\
\hline WCir & 7 & 0 & 0 & 7 & 0 & 0 & 0 & 7 & 0 & 3 & 4 & 0 & $\begin{array}{l}\text { ALCA (1 + } 1 \text { incl. energy payback period); CLCA (2); } \\
\text { LCA sys exp (1) }\end{array}$ & 1 & 1 & {$[63,68,83,92,93,96,98]$} \\
\hline WSup & 1 & 0 & 0 & 0 & 1 & 0 & 0 & 1 & 0 & 0 & 0 & 1 & ALCA incl. LCC (1) & 1 & 0 & [95] \\
\hline
\end{tabular}




\section{References}

1. Food and Agriculture Organization of the United Nations. The Future of Food and Agriculture: Trends and Challenges; Food and Agriculture Organization of the United Nations: Rome, Italy, 2017; ISBN 978-92-5-109551-5.

2. United Nations Department of Economic and Social Affairs. World Population Prospects. The 2017 Revision, Key Findings \& Advance Tables; United Nations: New York, NY, USA, 2017.

3. United Nations. DESA/Population Division World Urbanization Prospects: The 2018 Revision. Available online: https://population.un.org/wup/ (accessed on 31 January 2020).

4. Notarnicola, B.; Sala, S.; Anton, A.; McLaren, S.J.; Saouter, E.; Sonesson, U. The role of life cycle assessment in supporting sustainable agri-food systems: A review of the challenges. J. Clean. Prod. 2017, 140, 399-409. [CrossRef]

5. Popp, J.; Lakner, Z.; Harangi-Rákos, M.; Fári, M. The effect of bioenergy expansion: Food, energy, and environment. Renew. Sustain. Energy Rev. 2014, 32, 559-578. [CrossRef]

6. Organisation for Economic Co-operation and Development. OECD Environmental Outlook to 2050: The Consequences of Inaction; OECD: Paris, France, 2012; ISBN 978-92-64-12224-6.

7. Food and Agricultural Organization of the United Nations. Transforming Food and Agriculture to Achieve the SDGs; Food and Agricultural Organization of the United Nations: Rome, Italy, 2018; ISBN 978-92-5-130626-0.

8. Van Tongeren, F. Agricultural Policy Design and Implementation. A Synthesis; Organisation for Economic Co-operation and Development: Paris, France, 2008; p. 32.

9. McManus, M.C.; Taylor, C.M. The changing nature of life cycle assessment. Biomass Bioenergy 2015, 82, 13-26. [CrossRef] [PubMed]

10. Rajagopal, D.; Vanderghem, C.; MacLean, H.L. Life cycle assessment for economists. Annu. Rev. Resour. Econ. 2017, 9, 361-381. [CrossRef]

11. Hellweg, S.; Canals, M.L. Emerging approaches, challenges and opportunities in life cycle assessment. Science 2014, 344, 1109-1113. [CrossRef] [PubMed]

12. Goedkoop, M.; Martinez, E.V.; de Beer, I. LCA as the Tool to Measure Progress towards the Sustainable Development Goals; LIST: Luxembourg, 2017.

13. Sala, S.; Reale, F.; Cristobal-Garcia, J.; Pant, R. Life Cycle Assessment for the Impact Assessment of Policies; Publications Office: Luxembourg, 2016; ISBN 978-92-79-64813-7.

14. Horton, P.; Banwart, S.A.; Brockington, D.; Brown, G.W.; Bruce, R.; Cameron, D.; Holdsworth, M.; Lenny Koh, S.C.; Ton, J.; Jackson, P. An agenda for integrated system-wide interdisciplinary agri-food research. Food Sec. 2017, 9, 195-210. [CrossRef]

15. De Benedetto, L.; Klemeš, J. The environmental performance strategy map: An INTEGRATED LCA approach to support the strategic decision-making process. J. Clean. Prod. 2009, 17, 900-906. [CrossRef]

16. Creutzig, F.; Popp, A.; Plevin, R.; Luderer, G.; Minx, J.; Edenhofer, O. Reconciling top-down and bottom-up modelling on future bioenergy deployment. Nat. Clim. Chang. 2012, 2, 320-327. [CrossRef]

17. Freidberg, S. Calculating sustainability in supply chain capitalism. Econ. Soc. 2013, 42, 571-596. [CrossRef]

18. Seuring, S.; Gold, S. Conducting content-analysis based literature reviews in supply chain management. Supply Chain Manag. 2012, 17, 544-555. [CrossRef]

19. Gava, O.; Bartolini, F.; Venturi, F.; Brunori, G.; Zinnai, A.; Pardossi, A. A reflection of the use of the life cycle assessment tool for agri-food sustainability. Sustainability 2019, 11, 71. [CrossRef]

20. Baumann, H.; Tillman, A.-M. The Hitch Hikers's Guide to LCA: An Orientation in Life Cycle Assessment Methodology and Application; Studentlitteratur: Lund, Sweden, 2004; ISBN 978-91-44-02364-9.

21. Garnett, T. Three perspectives on sustainable food security: Efficiency, demand restraint, food system transformation. What role for life cycle assessment? J. Clean. Prod. 2014, 73, 10-18. [CrossRef]

22. Bryngelsson, D.; Wirsenius, S.; Hedenus, F.; Sonesson, U. How can the EU climate targets be met? A combined analysis of technological and demand-side changes in food and agriculture. Food Policy 2016, 59, 152-164. [CrossRef]

23. Dwivedi, S.L.; Lammerts van Bueren, E.T.; Ceccarelli, S.; Grando, S.; Upadhyaya, H.D.; Ortiz, R. Diversifying food systems in the pursuit of sustainable food production and healthy diets. Trends Plant Sci. 2017, 22, 842-856. [CrossRef] [PubMed] 
24. Godfray, H.C.J.; Beddington, J.R.; Crute, I.R.; Haddad, L.; Lawrence, D.; Muir, J.F.; Pretty, J.; Robinson, S.; Thomas, S.M.; Toulmin, C. Food security: The challenge of feeding 9 billion people. Science 2010, 327, 812-818. [CrossRef] [PubMed]

25. Foley, J.A.; Ramankutty, N.; Brauman, K.A.; Cassidy, E.S.; Gerber, J.S.; Johnston, M.; Mueller, N.D.; O'Connell, C.; Ray, D.K.; West, P.C.; et al. Solutions for a cultivated planet. Nature 2011, 478, 337-342. [CrossRef]

26. Reynolds, C.; Goucher, L.; Quested, T.; Bromley, S.; Gillick, S.; Wells, V.K.; Evans, D.; Koh, L.; Carlsson Kanyama, A.; Katzeff, C.; et al. Review: Consumption-stage food waste reduction interventions-What works and how to design better interventions. Food Policy 2019, 83, 7-27. [CrossRef]

27. Friedman, A.L.; Miles, S. Stakeholders: Theory and Practice; Oxford University Press: Oxford, UK, 2006; ISBN 978-0-19-926987-7.

28. Font Vivanco, D.; van der Voet, E. The rebound effect through industrial ecology's eyes: A review of LCA-based studies. Int. J. Life Cycle Assess. 2014, 19, 1933-1947. [CrossRef]

29. Halloran, A.; Clement, J.; Kornum, N.; Bucatariu, C.; Magid, J. Addressing food waste reduction in Denmark. Food Policy 2014, 49, 294-301. [CrossRef]

30. Jeswani, H.K.; Azapagic, A.; Schepelmann, P.; Ritthoff, M. Options for broadening and deepening the LCA approaches. J. Clean. Prod. 2010, 18, 120-127. [CrossRef]

31. Settanni, E.; Notarnicola, B.; Tassielli, G. Combining life cycle assessment of food products with economic tools. In Environmental Assessment and Management in the Food Industry; Woodhead Publishing Limited: Sawston, UK, 2010; pp. 207-218. ISBN 978-1-84569-552-1.

32. Finkbeiner, M.; Schau, E.M.; Lehmann, A.; Traverso, M. Towards life cycle sustainability assessment. Sustainability 2010, 2, 3309-3322. [CrossRef]

33. Zamagni, A. Life cycle sustainability assessment. Int. J. Life Cycle Assess. 2012, 17, 373-376. [CrossRef]

34. Valdivia, S.; Ugaya, C.M.L.; Hildenbrand, J.; Traverso, M.; Mazijn, B.; Sonnemann, G. A UNEP/SETAC approach towards a life cycle sustainability assessment-Our contribution to Rio+20. Int. J. Life Cycle Assess. 2013, 18, 1673-1685. [CrossRef]

35. Cavanagh, S. Content analysis: Concepts, methods and applications. Nurse Res. 1997, 4, 5-13. [CrossRef]

36. Elo, S.; Kyngäs, H. The qualitative content analysis process. J. Adv. Nurs. 2008, 62, 107-115. [CrossRef]

37. Neuendorf, K.A. The Content Analysis Guidebook, 2nd ed.; Sage: Los Angeles, CA, USA, 2017; ISBN 978-1-4129-7947-4.

38. Downe-Wamboldt, B. Content analysis: Method, applications, and issues. Health Care Women Int. 1992, 13, 313-321. [CrossRef]

39. Weber, R.P. Basic Content Analysis; Sage Publications, Inc.: Thousand Oaks, CA, USA, 1990; ISBN 978-1-4129-8348-8.

40. Krippendorff, K. Content Analysis: An Introduction to its Methodology, 2nd ed.; Sage: Thousand Oaks, CA, USA, 2004; ISBN 978-0-7619-1544-7.

41. Mayring, P. Qualitative Content Analysis: Theoretical Foundation, Basic Procedures and Software Solution; GESIS: Klagenfurt, Austria, 2014.

42. Hagen-Zanker, J.; Mallet, R. How to Do a Rigorous, Evidence-Focused Literature Review in International Development, A Guidance Note; Overseas Development Institute: London, UK, 2013.

43. Fink, A. Conducting Research Literature Reviews: From the Internet to Paper, 4th ed.; Sage: Thousand Oaks, CA, USA, 2014; ISBN 978-1-4522-5949-9.

44. Tranfield, D.; Denyer, D.; Smart, P. Towards a methodology for developing evidence-informed management knowledge by means of systematic review. Br. J. Manag. 2003, 14, 207-222. [CrossRef]

45. Beske, P.; Land, A.; Seuring, S. Sustainable supply chain management practices and dynamic capabilities in the food industry: A critical analysis of the literature. Int. J. Prod. Econ. 2014, 152, 131-143. [CrossRef]

46. Kirchherr, J.; Reike, D.; Hekkert, M. Conceptualizing the circular economy: An analysis of 114 definitions. Resour. Conserv. Recycl. 2017, 127, 221-232. [CrossRef]

47. Govindan, K.; Hasanagic, M. A systematic review on drivers, barriers, and practices towards circular economy: A supply chain perspective. Int. J. Prod. Res. 2018, 56, 278-311. [CrossRef]

48. Organisation for Economic Co-operation and Development. Frascati Manual 2015: Guidelines for Collecting and Reporting Data on Research and Experimental Development; OECD: Paris, France, 2015; ISBN 978-92-64-26208-9. 
49. Bartol, T.; Budimir, G.; Juznic, P.; Stopar, K. Mapping and classification of agriculture in Web of Science: Other subject categories and research fields may benefit. Scientometrics 2016, 109, 979-996. [CrossRef]

50. Abramo, G.; D'Angelo, C.A. Evaluating research: From informed peer review to bibliometrics. Scientometrics 2011, 87, 499-514. [CrossRef]

51. Herrmann, R.; Berg, E.; Dabbert, S.; Pöchtrager, S.; Salhofer, K. Going beyond impact factors: A survey-based journal ranking by agricultural economists: Ranking of journals relevant for agricultural economists. J. Agric. Econ. 2011, 62, 710-732. [CrossRef]

52. Rigby, D.; Burton, M.; Lusk, J.L. Journals, preferences, and publishing in agricultural and environmental economics. Am. J. Agric. Econ. 2015, 97, 490-509. [CrossRef]

53. Rajaeian, M.M.; Cater-Steel, A.; Lane, M. Do they read your research? An investigation of practitioners' use of IT outsourcing and cloud sourcing research. In Proceedings of the 27th Australasian Conference on Information Systems (ACIS 2016), Wollongong, NSW, Australia, 5-7 December 2016.

54. Hou, Q.; Mao, G.; Zhao, L.; Du, H.; Zuo, J. Mapping the scientific research on life cycle assessment: A bibliometric analysis. Int. J. Life Cycle Assess. 2015, 20, 541-555. [CrossRef]

55. De Luca, A.I.; Iofrida, N.; Leskinen, P.; Stillitano, T.; Falcone, G.; Strano, A.; Gulisano, G. Life cycle tools combined with multi-criteria and participatory methods for agricultural sustainability: Insights from a systematic and critical review. Sci. Total Environ. 2017, 595, 352-370. [CrossRef]

56. Carlsson-Kanyama, A. Climate change and dietary choices-How can emissions of greenhouse gases from food consumption be reduced? Food Policy 1998, 23, 277-293. [CrossRef]

57. Mouron, P.; Scholz, R.W.; Nemecek, T.; Weber, O. Life cycle management on Swiss fruit farms: Relating environmental and income indicators for apple-growing. Ecol. Econ. 2006, 58, 561-578. [CrossRef]

58. Pizzigallo, A.C.I.; Granai, C.; Borsa, S. The joint use of LCA and energy evaluation for the analysis of two Italian wine farms. J. Environ. Manag. 2008, 86, 396-406. [CrossRef]

59. Basset-Mens, C.; Ledgard, S.; Boyes, M. Eco-efficiency of intensification scenarios for milk production in New Zealand. Ecol. Econ. 2009, 68, 1615-1625. [CrossRef]

60. Blengini, G.A.; Busto, M. The life cycle of rice: LCA of alternative agri-food chain management systems in Vercelli (Italy). J. Environ. Manag. 2009, 90, 1512-1522. [CrossRef]

61. Thomassen, M.A.; Dolman, M.A.; van Calker, K.J.; de Boer, I.J.M. Relating life cycle assessment indicators to gross value added for Dutch dairy farms. Ecol. Econ. 2009, 68, 2278-2284. [CrossRef]

62. Beccali, M.; Cellura, M.; Iudicello, M.; Mistretta, M. Life cycle assessment of Italian citrus-based products. Sensitivity analysis and improvement scenarios. J. Environ. Manag. 2010, 91, 1415-1428. [CrossRef] [PubMed]

63. Morris, C.; Jorgenson, W.; Snellings, S. Carbon and energy life-cycle assessment for five agricultural anaerobic digesters in Massachusetts on small dairy farms. Int. Food Agribus. Manag. Rev. 2010, 13, 121-127.

64. Prudêncio da Silva, V.; van der Werf, H.M.G.; Spies, A.; Soares, S.R. Variability in environmental impacts of Brazilian soybean according to crop production and transport scenarios. J. Environ. Manag. 2010, 91, 1831-1839. [CrossRef] [PubMed]

65. González, A.D.; Frostell, B.; Carlsson-Kanyama, A. Protein efficiency per unit energy and per unit greenhouse gas emissions: Potential contribution of diet choices to climate change mitigation. Food Policy 2011, 36, 562-570. [CrossRef]

66. Hallström, E.; Röös, E.; Börjesson, P. Sustainable meat consumption: A quantitative analysis of nutritional intake, greenhouse gas emissions and land use from a Swedish perspective. Food Policy 2014, 47, 81-90. [CrossRef]

67. Cellura, M.; Ardente, F.; Longo, S. From the LCA of food products to the environmental assessment of protected crops districts: A case-study in the south of Italy. J. Environ. Manag. 2012, 93, 194-208. [CrossRef]

68. de Alvarenga, R.A.F.; Galindro, B.M.; de Fátima Helpa, C.; Soares, S.R. The recycling of oyster shells: An environmental analysis using life cycle assessment. J. Environ. Manag. 2012, 106, 102-109. [CrossRef]

69. Devers, L.; Kleynhans, T.E.; Mathijs, E. Comparative life cycle assessment of Flemish and Western Cape pork production. Agrekon 2012, 51, 105-128. [CrossRef]

70. Nijdam, D.; Rood, T.; Westhoek, H. The price of protein: Review of land use and carbon footprints from life cycle assessments of animal food products and their substitutes. Food Policy 2012, 37, 760-770. [CrossRef]

71. Roy, P.; Orikasa, T.; Thammawong, M.; Nakamura, N.; Xu, Q.; Shiina, T. Life cycle of meats: An opportunity to abate the greenhouse gas emission from meat industry in Japan. J. Environ. Manag. 2012, 93, 218-224. [CrossRef] [PubMed] 
72. Vázquez-Rowe, I.; Villanueva-Rey, P.; Moreira, M.T.; Feijoo, G. Environmental analysis of Ribeiro wine from a timeline perspective: Harvest year matters when reporting environmental impacts. J. Environ. Manag. 2012, 98, 73-83. [CrossRef] [PubMed]

73. Brodt, S.; Kramer, K.J.; Kendall, A.; Feenstra, G. Comparing environmental impacts of regional and national-scale food supply chains: A case study of processed tomatoes. Food Policy 2013, 42, 106-114. [CrossRef]

74. Dong, G.; Mao, X.; Zhou, J.; Zeng, A. Carbon footprint accounting and dynamics and the driving forces of agricultural production in Zhejiang Province, China. Ecol. Econ. 2013, 91, 38-47. [CrossRef]

75. McFadden, B.R.; Nalley, L.L.; Popp, M.P. How greenhouse gas emission policy and industry pressure could affect producer selection of rice cultivars. Agric. Resour. Econ. Rev. 2013, 42, 325-348. [CrossRef]

76. Nguyen, T.T.H.; Doreau, M.; Corson, M.S.; Eugène, M.; Delaby, L.; Chesneau, G.; Gallard, Y.; van der Werf, H.M.G. Effect of dairy production system, breed and co-product handling methods on environmental impacts at farm level. J. Environ. Manag. 2013, 120, 127-137. [CrossRef]

77. Pergola, M.; D’Amico, M.; Celano, G.; Palese, A.M.; Scuderi, A.; Di Vita, G.; Pappalardo, G.; Inglese, P. Sustainability evaluation of Sicily's lemon and orange production: An energy, economic and environmental analysis. J. Environ. Manag. 2013, 128, 674-682. [CrossRef]

78. Spinelli, D.; Bardi, L.; Fierro, A.; Jez, S.; Basosi, R. Environmental analysis of sunflower production with different forms of mineral nitrogen fertilizers. J. Environ. Manag. 2013, 129, 302-308. [CrossRef]

79. Vázquez-Rowe, I.; Villanueva-Rey, P.; Moreira, M.T.; Feijoo, G. The role of consumer purchase and post-purchase decision-making in sustainable seafood consumption. A Spanish case study using carbon footprinting. Food Policy 2013, 41, 94-102. [CrossRef]

80. Wilfart, A.; Prudhomme, J.; Blancheton, J.-P.; Aubin, J. LCA and emergy accounting of aquaculture systems: Towards ecological intensification. J. Environ. Manag. 2013, 121, 96-109. [CrossRef] [PubMed]

81. Benedetto, G.; Rugani, B.; Vázquez-Rowe, I. Rebound effects due to economic choices when assessing the environmental sustainability of wine. Food Policy 2014, 49, 167-173. [CrossRef]

82. Eory, V.; MacLeod, M.; Shrestha, S.; Roberts, D. Linking an economic and a life-cycle analysis biophysical model to support agricultural greenhouse gas mitigation policy-Kombination eines ökonomischen modells mit einem bio-physikalischen lebenszyklus-modell zur unterstützung von Politikmaßnahmen zur verringerung von treibhausgasen. Ger. J. Agric. 2014, 63, 133-142.

83. Ten Hoeve, M.; Hutchings, N.J.; Peters, G.M.; Svanström, M.; Jensen, L.S.; Bruun, S. Life cycle assessment of pig slurry treatment technologies for nutrient redistribution in Denmark. J. Environ. Manag. 2014, 132, 60-70. [CrossRef]

84. Van Dooren, C.; Marinussen, M.; Blonk, H.; Aiking, H.; Vellinga, P. Exploring dietary guidelines based on ecological and nutritional values: A comparison of six dietary patterns. Food Policy 2014, 44, 36-46. [CrossRef]

85. Coderoni, S.; Valli, L.; Canavari, M. Climate change mitigation options in the Italian livestock sector. EuroChoices 2015, 14, 17-24. [CrossRef]

86. Meier, M.S.; Stoessel, F.; Jungbluth, N.; Juraske, R.; Schader, C.; Stolze, M. Environmental impacts of organic and conventional agricultural products-Are the differences captured by life cycle assessment? J. Environ. Manag. 2015, 149, 193-208. [CrossRef]

87. Robert Kiefer, L.; Menzel, F.; Bahrs, E. Integration of ecosystem services into the carbon footprint of milk of South German dairy farms. J. Environ. Manag. 2015, 152, 11-18. [CrossRef]

88. Cerutti, A.K.; Contu, S.; Ardente, F.; Donno, D.; Beccaro, G.L. Carbon footprint in green public procurement: Policy evaluation from a case study in the food sector. Food Policy 2016, 58, 82-93. [CrossRef]

89. Chen, W.; White, E.; Holden, N.M. The effect of lameness on the environmental performance of milk production by rotational grazing. J. Environ. Manag. 2016, 172, 143-150. [CrossRef]

90. Ghasempour, A.; Ahmadi, E. Assessment of environment impacts of egg production chain using life cycle assessment. J. Environ. Manag. 2016, 183, 980-987. [CrossRef]

91. Goldstein, B.; Hansen, S.F.; Gjerris, M.; Laurent, A.; Birkved, M. Ethical aspects of life cycle assessments of diets. Food Policy 2016, 59, 139-151. [CrossRef]

92. Komakech, A.J.; Zurbrügg, C.; Miito, G.J.; Wanyama, J.; Vinnerås, B. Environmental impact from vermicomposting of organic waste in Kampala, Uganda. J. Environ. Manag. 2016, 181, 395-402. [CrossRef] 
93. Nayal, F.S.; Mammadov, A.; Ciliz, N. Environmental assessment of energy generation from agricultural and farm waste through anaerobic digestion. J. Environ. Manag. 2016, 184, 389-399. [CrossRef]

94. Röös, E.; Patel, M.; Spångberg, J.; Carlsson, G.; Rydhmer, L. Limiting livestock production to pasture and by-products in a search for sustainable diets. Food Policy 2016, 58, 1-13. [CrossRef]

95. Todorovic, M.; Mehmeti, A.; Scardigno, A. Eco-efficiency of agricultural water systems: Methodological approach and assessment at meso-level scale. J. Environ. Manag. 2016, 165, 62-71. [CrossRef]

96. Van Stappen, F.; Mathot, M.; Decruyenaere, V.; Loriers, A.; Delcour, A.; Planchon, V.; Goffart, J.-P.; Stilmant, D. Consequential environmental life cycle assessment of a farm-scale biogas plant. J. Environ. Manag. 2016, 175, 20-32. [CrossRef]

97. Dakpo, K.H.; Jeanneaux, P.; Latruffe, L. Greenhouse gas emissions and efficiency in French sheep meat farming: A non-parametric framework of pollution-adjusted technologies. Eur. Rev. Agric. Econ. 2017, 44, 33-65. [CrossRef]

98. Hanifzadeh, M.; Nabati, Z.; Longka, P.; Malakul, P.; Apul, D.; Kim, D.-S. Life cycle assessment of superheated steam drying technology as a novel cow manure management method. J. Environ. Manag. 2017, 199, 83-90. [CrossRef]

99. Rice, P.; O'Brien, D.; Shalloo, L.; Holden, N.M. Evaluation of allocation methods for calculation of carbon footprint of grass-based dairy production. J. Environ. Manag. 2017, 202, 311-319. [CrossRef]

100. Salvador, S.; Corazzin, M.; Romanzin, A.; Bovolenta, S. Greenhouse gas balance of mountain dairy farms as affected by grassland carbon sequestration. J. Environ. Manag. 2017, 196, 644-650. [CrossRef] [PubMed]

101. Tsiboe, F.; Nalley, L.L.; Durand, A.; Greg, T.; Aaron, S. The economic and environmental benefits of sheath blight resistance in rice. J. Agric. Resour. Econ. 2017, 42, 215-235.

102. Yodkhum, S.; Gheewala, S.H.; Sampattagul, S. Life cycle GHG evaluation of organic rice production in northern Thailand. J. Environ. Manag. 2017, 196, 217-223. [CrossRef]

103. Seuring, S.; Müller, M.; Westhaus, M.; Morana, R. Conducting a literature review-The example of sustainability in supply chains. In Research Methodologies in Supply Chain Management; Physica-Verlag: Heidelberg, Germany, 2005; pp. 91-106. ISBN 978-3-7908-1636-5.

104. Wasserman, S.; Faust, K. Social Network Analysis: Methods and Applications; Structural Analysis in the Social Sciences Book Series; Cambridge University Press: Cambridge, UK, 1994; ISBN 978-0-521-38269-4.

105. Cowhitt, T.; Butler, T.; Wilson, E. Using social network analysis to complete literature reviews: A new systematic approach for independent researchers to detect and interpret prominent research programs within large collections of relevant literature. Int. J. Soc. Res. Methodol. 2019, 0, 1-14. [CrossRef]

106. Lamb, J.N.; Moore, K.M.; Norton, J.; Omondi, E.C.; Laker-Ojok, R.; Sikuku, D.N.; Ashilenje, D.S.; Odera, J. A social networks approach for strengthening participation in technology innovation: Lessons learnt from the Mount Elgon region of Kenya and Uganda. Int. J. Agric. Sustain. 2016, 14, 65-81. [CrossRef]

107. Borgatti, S.P. Centrality and network flow. Soc. Netw. 2005, 27, 55-71. [CrossRef]

108. Borgatti, S.P.; Everett, M.G.; Freeman, L.C. Ucinet 6 for Windows: Software for Social Network Analysis; Analytic Technologies: Harvard, MA, USA, 2002.

109. Garnett, T. Where are the best opportunities for reducing greenhouse gas emissions in the food system (including the food chain)? Food Policy 2011, 36, S23-S32. [CrossRef]

110. Reale, F.; Cinelli, M.; Sala, S. Towards a research agenda for the use of LCA in the impact assessment of policies. Int. J. Life Cycle Assess. 2017, 22, 1477-1481. [CrossRef]

111. Pretty, J.; Benton, T.G.; Bharucha, Z.P.; Dicks, L.V.; Flora, C.B.; Godfray, H.C.J.; Goulson, D.; Hartley, S.; Lampkin, N.; Morris, C.; et al. Global assessment of agricultural system redesign for sustainable intensification. Nat. Sustain. 2018, 1, 441-446. [CrossRef]

112. Weinrich, R.; Spiller, A. Developing food labelling strategies: Multi-level labelling. J. Clean. Prod. 2016, 137, 1138-1148. [CrossRef]

113. Röös, E.; Mie, A.; Wivstad, M.; Salomon, E.; Johansson, B.; Gunnarsson, S.; Wallenbeck, A.; Hoffmann, R.; Nilsson, U.; Sundberg, C.; et al. Risks and opportunities of increasing yields in organic farming. A review. Agron. Sustain. Dev. 2018, 38, 14. [CrossRef]

114. Pe'er, G.; Zinngrebe, Y.; Moreira, F.; Sirami, C.; Schindler, S.; Müller, R.; Bontzorlos, V.; Clough, D.; Bezák, P.; Bonn, A.; et al. A greener path for the EU Common Agricultural Policy. Science 2019, 365, 449-451. [CrossRef] [PubMed] 
115. Flanagan, K.; Uyarra, E.; Laranja, M. Reconceptualising the 'policy mix' for innovation. Res. Policy 2011, 40, 702-713. [CrossRef]

116. Mazzucato, M. Mission-oriented innovation policies: Challenges and opportunities. Ind. Corp. Chang. 2018, 27, 803-815. [CrossRef]

117. Kanter, D.R.; Bartolini, F.; Kugelberg, S.; Leip, A.; Oenema, O.; Uwizeye, A. Nitrogen pollution policy beyond the farm. Nat. Food 2019, 1, 27-32. [CrossRef]

118. Capodaglio, A.; Callegari, A.; Lopez, M. European framework for the diffusion of biogas uses: Emerging technologies, acceptance, incentive strategies, and institutional-regulatory support. Sustainability 2016, 8 , 298. [CrossRef]

119. Nepal, R.; Jamasb, T.; Sen, A. Small systems, big targets: Power sector reforms and renewable energy in small systems. Energy Policy 2018, 116, 19-29. [CrossRef]

120. Garnett, T. Plating up solutions. Science 2016, 353, 1202-1204. [CrossRef]

121. Leach, A.M.; Emery, K.A.; Gephart, J.; Davis, K.F.; Erisman, J.W.; Leip, A.; Pace, M.L.; D’Odorico, P.; Carr, J.; Noll, L.C.; et al. Environmental impact food labels combining carbon, nitrogen, and water footprints. Food Policy 2016, 61, 213-223. [CrossRef]

122. Gadema, Z.; Oglethorpe, D. The use and usefulness of carbon labelling food: A policy perspective from a survey of UK supermarket shoppers. Food Policy 2011, 36, 815-822. [CrossRef]

123. Apostolidis, C.; McLeay, F. Should we stop meating like this? Reducing meat consumption through substitution. Food Policy 2016, 65, 74-89. [CrossRef]

124. Lusk, J.L. Evaluating the policy proposals of the food movement. Appl. Econ. Perspect. Policy 2017, 39, 387-406. [CrossRef]

125. Bombelli, A.; Di Paola, A.; Chiriacò, M.V.; Perugini, L.; Castaldi, S.; Valentini, R. Climate change, sustainable agriculture and food systems: The world after the Paris agreement. In Achieving the Sustainable Development Goals Through Sustainable Food Systems; Valentini, R., Sievenpiper, J.L., Antonelli, M., Dembska, K., Eds.; Springer International Publishing: Cham, Switzerland, 2019; pp. 25-34. ISBN 978-3-030-23969-5.

(C) 2020 by the authors. Licensee MDPI, Basel, Switzerland. This article is an open access article distributed under the terms and conditions of the Creative Commons Attribution (CC BY) license (http://creativecommons.org/licenses/by/4.0/). 